\title{
Five new species of genus Astyanax Baird \& Girard, 1854 from Rio Iguaçu, Paraná, Brazil (Ostariophysi, Characiformes, Characidae)
}

\author{
Garavello, JC. ${ }^{\text {** }}$ and Sampaio, FAA. ${ }^{\mathrm{b}}$ \\ aDepartamento de Ecologia e Biologia Evolutiva, Universidade Federal de São Carlos - UFSCar, \\ Rod. Washington Luís, Km 235, CEP 13565-905, São Carlos, SP, Brazil \\ bPrograma de Pós-graduação em Ecologia e Recursos Naturais - PPG-ERN, \\ Universidade Federal de São Carlos - UFSCar, Rod. Washington Luís, Km 235, \\ CEP 13565-905, São Carlos, SP, Brazil \\ *e-mail: garavelo@ufscar.br \\ Received January 8, 2010 - Accepted July 5, 2010 - Distributed October 31, 2010
}

(With 9 figures)

\begin{abstract}
Five new species of the Neotropical characiform genus Astyanax Baird \& Girard are described from Rio Iguaçu at the border of Paraná and Santa Catarina states, southeastern Brazil and Astyanax gymnogenis Eigenmann is redescribed. Each new species can be distinguished from all other Astyanax species from the upper Rio Paraná basin by exclusive combinations of: tooth shape, number of dental cuspids, distance between third infraorbital and preopercle, number of lateral line scales, longitudinal series of scales, number of gill-rakers and differences from shape of body and head traits. This study proposes the species of genus Astyanax from Rio Iguaçu as probably endemic, since all of them are absent from tributaries of the Rio Paraná hydrographic system. The high degree of diversification acquired by those Astyanax species in the Iguaçu basin may perhaps be allied to the long isolation period of this river from the Rio Paraná basin caused by the Iguaçu waterfalls. This barrier probably isolated those basins resulting in original groups of Characiformes and then Astyanax species, both isolated from one another and both different from their relatives in neighbouring basins.
\end{abstract}

Keywords: freshwaterfishes, Ostariophysi, taxonomy, Characidae, Astyanax, neotropics.

\author{
Cinco novas espécies do gênero Astyanax Baird \& Girard, 1854 do \\ Rio Iguaçu, Paraná, Brasil (Ostariophysi, Characiformes, Characidae)
}

\section{Resumo}

Cinco novas espécies do gênero Astyanax Baird \& Girard da bacia do Rio Iguaçu na fronteira do Paraná e Santa Catarina, região sudeste do Brasil são descritas e Astyanax gymnogenis Eigenmann é redescrita. Cada nova espécie se diferencia das demais do gênero Astyanax na bacia do Rio Paraná por combinações únicas de: forma dos dentes, número de cúspides, distância entre o terceiro infraorbital e o pré-opérculo, contagens de escamas da linha lateral, séries longitudinais de escamas, rastros branquiais e diferenças morfométricas na cabeça e tronco. A bacia do Rio Iguaçu apresenta espécies do gênero Astyanax, provavelmente endêmicas, e nenhuma delas ocorrendo nos rios da bacia do Rio Paraná. É discutido, neste artigo, se o elevado endemismo de espécies do gênero Astyanax nessa bacia hidrográfica estaria relacionado ao longo período de isolamento causado pelas Cataratas do Iguaçu, que separou o Rio Iguaçu do Rio Paraná no passado geológico, diversificando a ictiofauna de Characiformes e diferenciando-a em relação à da bacia do Rio Paraná.

Palavras-chave: peixes de água doce, Ostariophysi, taxonomia, Characidae, Astyanax, neotropical. 


\section{Introduction}

The genus Astyanax as defined by Baird and Girard (1854) based on Astyanax argentatus, was included as "Characini" fishes with an adipose fin present, characterised by an abdominal line not serrate, double rows of teeth on both jaws, flattened and with several conic spines or processes upon their edge; without canine or palatine teeth, dorsal fin above the pelvic fins and with large scales. The last complete revision of Astyanax was published by Eigenmann (1921-1927) and included seventy-four species and subspecies distributed from Rio Grande at the Mexico and United States border to south Brazil, Uruguay and Argentina. Eigenmann diagnosed the genus Astyanax as "compressed fishes, more or less elongate, rarely reaching a length of $150 \mathrm{~mm}$ SL, usually much smaller, but in one instance, A. maximus, reaching $200 \mathrm{~mm}$ in length; premaxillary with two series of teeth, the first series with several teeth; mandible with strong teeth in front, abruptly minute conical ones on the sides, without conical teeth in a second series; teeth of second series of premaxillary equal or graduated, usually five in number, four in a few species; crowns of premaxillary and mandibulary teeth usually ridged and denticulate; maxillary with a few or no (0-10) teeth; caudal naked; lateral line complete; gillrakers setiform; no predoral spine". After this revision by Eigenmann, only a comprehensive summary by Géry (1977) identified more than 60 species, including synonyms considering new subspecies, in a taxonomic proposal on the basis of Eigenmann's arrangement. Since Eigenmann's studies, Astyanax is considered one of the most specious genera of order Characiformes. Recently, Lima et al. (2003) considered the genus Astyanax as Incertae Sedis and with 85 species.

With reference to the upper Rio Paraná above the former Sete Quedas Falls, six nominal species were described, but according to Garutti and Britski (2000), only four could be recognised: Astyanax paranahybae Eigenmann, 1911, Astyanax scabripinnis paranae Eigenmann, 1914, Astyanax schubarti Britski, 1964 and Astyanax altiparanae Garutti \& Britski, 2000. They also examined the taxonomic status of Astyanax trierythropterus Godoy, 1970 and Astyanax bipunctialbicaudalis Godoy, 1977, both from Rio Mogi-Guaçu, and examined references to Astyanax fasciatus (Cuvier, 1819) and Astyanax eigenmanniorum (Cope, 1894) for Rio Paraná. Azpelicueta et al. (2002) and Casciotta et al. (2003) had described new species for this genus from Rio Paraná, Argentina. From south Brazil, Bertaco and Malabarba (2001) describe two species related to Astyanax scabripinnis (Jenyns, 1842), one of them from the headwaters of Rio Uruguay. Melo and Buckup (2006) provide a new name for Tetragonopterus aeneus Hensel, 1870.

On the other hand, contributions to systematic of genus Astyanax in Rio Iguaçu comes from Eigenmann (1911b), who studied the Haseman's ichthyological collection and describe Astyanax gymnogenis, the genus Psalidodon, and new species for genera Hyphessobrycon and Glandulocauda.
In 1921 and 1927 Eigenmann also cite Astyanax scabripinnis paranae and Astyanax eigenmanniorum for Rio Iguaçu.

In addition, the high endemism shown by the Astyanax species in Rio Iguaçu above Iguaçu waterfalls, has been recognised since Haseman (1911b), who observed the great diversity of Characiformes from Rio Paraná, when compared to the low number of fish families of this order from Iguaçu. The Iguaçu waterfalls produce a physical isolation between the rivers Iguaçu and Paraná. This fact was used by Haseman to explain the absence of a large number of migratory characiform fish species in Iguaçu; however, he did not discuss this matter regarding the Astyanax species diversification in this basin.

Fifty years later, Garavello (1977), when describing Apareiodon vittatus, examined the question of isolation of Rio Iguaçu ichthyofauna, mentioning several undescribed species for Astyanax in this basin. Godoy (1979), studying fishes from Segredo reservoir at medium Iguaçu, gave a short list of species including a reference to an unidentified Astyanax species. Menezes and Géry (1983) contributed with the description of Oligosarcus longirostris, observing the restriction of this species to above the Iguaçu waterfalls. In 1988, Sampaio (unpublished) revised the specific status of the characiform ichthyofauna of Rio Iguaçu, including diagnosis for some undescribed Astyanax species. After Sampaio, Severi and Cordeiro (1994) compiling Sampaio, catalogued the same Astyanax species as recognised by this last author.

Garavello et al. (1997) provided diagnosis for six species of genus Astyanax and made mention to A. bimaculatus and A. gymnogenis from Rio Iguaçu. Following on, Almirón et al. (2002) describe Astyanax ita from lower Iguaçu next to Argentina. At the present time, Astyanax totae has been described from Iguaçu headwaters by Haluch and Abilhoa (2005); Abilhoa and Duboc (2007) also described Astyanax varzeae from headwaters of Rio Negro, and as a final point, Alcaraz et al. (2009) described Astyanax jordanensis from Rio Jordão, all three species described as allied to Astyanax scabripinnis (Jenyns, 1842).

In the present study we describe five new species for genus Astyanax from Rio Iguaçu and redescribe Astyanax gymnogenis Eigenmann, remarking the references given to: Astyanax scabripinnis and A. eigenmaniorum by Eigenmann (1921, 1927); A. altiparanae by Graça and Pavanelli (2002), and other references to species of Astyanax by Ingenito et al. (2004). The present study also examines the high diversity of Astyanax species in the Rio Iguaçu and puts forward a discussion on the reasons that might have produced an amount of probably endemic Astyanax species at Iguaçu, and distinguishes them from their relatives from Rio Paraná.

\section{Material and Methods}

The specimens used in this study are housed in the following institutions: Museu de Zoologia, Universidade de São Paulo, São Paulo (MZUSP); Museu Nacional, Rio de Janeiro (MNRJ); Museu de História Natural Capão 
da Imbuia, Curitiba (MHNCI); Field Museum of Natural History, Chicago (FMNH); Academy of Natural Sciences of Philadelphia, Philadelphia (ANSP); California Academy of Sciences Museum, San Francisco (CAS); Nucleo de Pesquisas em Limnologia, Ictiologia e Aqüicultura, Maringá (NUP) and Laboratório de Ictiologia Sistemática, Departamento de Ecologia e Biologia Evolutiva, Universidade Federal de São Carlos, São Carlos (LISDEBE). Type specimens of all new species of genus Astyanax herein described are placed at MZUSP, MHNCI, FMNH, NUP and LISDEBE. Institutional abbreviations follow Leviton et al. (1985), with the addition of Laboratório de Ictiologia Sistemática do Departamento de Ecologia e Biologia Evolutiva da Universidade Federal de São Carlos (LISDEBE) and Núcleo de Pesquisas em Limnologia, Ictiologia e Aquicultura, Maringá (NUP).

Meristic characters were taken under the stereomicroscope, following basically Fink and Weitzman (1974). All teeth of both arcades were counted, but only those of the left side were considered. The number of unbranched fin rays is indicated by Roman characters, and branched rays by Arabic numerals. Gill-rakers were counted on first left branchial arch. The following counts were taken: 1) Number of teeth on premaxillary; 2) Number of teeth on dentary; 3) Number of teeth on maxillary; 4) Number of scales in lateral line; 5) Number of scales in transversal line; 6) Number of circumpeduncular scale series; 7) Number of dorsal-fin rays; 8) Number of pectoral-fin rays; 9) Number of pelvic-fin rays; 10) Number of anal-fin rays; 11) Number of caudal fin rays; 12) Number of gill-rakers on first left-side branchial arch. Counts were herein utilised for differential diagnosis of all species.

Measurements from specimens were taken with vernier calipers to nearest millimeter. The following sets of dimensions were taken: 1) Standard length: from tip of snout to base of caudal fin; 2) Head length: from tip of snout to posterior margin of opercle; 3) Snout length: from tip of snout to anterior margin of orbit; 4) Predorsal distance: from tip of snout to anterior base of first dorsal ray; 5) Preanal distance: from tip of snout to base of anal fin insertion; 6) Length of base of adipose fin; 7) Caudal peduncle depth: shorter distance from caudal peduncle; 8) Head depth: taken at occipital region; 9) Body depth: at dorsal fin origin; 10) Orbital diameter: taken horizontally; 11) Interorbital width: taken between eyes; 12) Mouth width: width of lower jaw. Those measurements were useful in meristic comparisons and they are expressed as proportions of body and head length inside diagnosis and in Tables 1, 2 and 3.

Type-material examined: Astyanax scabripinnis paranae Eigenmann, Tetragonopterus eigenmanniorum Cope, Astyanax ribeirae Eigenmann, Astyanax paranahybae Eigenmann, Astyanax gymnogenis Eigenmann; Astyanax hasemani Eigenmann; Astyanax bimaculatus novae Eigenmann; Astyanax bimaculatus paraguayensis Eigenmann; Astyanax schubarti Britski; Astyanax unicus Travassos

Table 1. Morphometric and meristic data of Astyanax gymnogenis and Astyanax longirhynus stated as percents of SL and HL.

\begin{tabular}{|c|c|c|c|c|c|c|c|c|}
\hline \multirow[t]{2}{*}{$(\mathbf{m m})$} & \multicolumn{4}{|c|}{ Astyanax gymnogenis $(n=14)$} & \multicolumn{4}{|c|}{ Astyanax longirhinus $(\mathrm{n}=16)$} \\
\hline & Holotype & Range & Mean & SD & Holotype & Range & Mean & SD \\
\hline Standard length (SL) & 66.5 & $138.8-146.5$ & 143.6 & 3.490 & 156.9 & $86.3-186.0$ & 146.6 & 4.808 \\
\hline \multicolumn{9}{|l|}{ Percents of standard length } \\
\hline Body depth & 37.0 & $35.7-39.0$ & 36.8 & 1.534 & 53.6 & $31.9-39.9$ & 34.9 & 3.488 \\
\hline Head length & 27.0 & $22.9-25.1$ & 24.0 & 0.915 & 41.0 & $25.6-26.5$ & 26.1 & 0.419 \\
\hline Predorsal distance & 43.0 & $51.7-54.1$ & 52.7 & 1.059 & 72.0 & $46.2-53.9$ & 49.3 & 3.301 \\
\hline Pectoral-fin length & 18.9 & $19.6-20.1$ & 19.9 & 0.204 & 31.8 & $17.2-20.4$ & 19.1 & 1.528 \\
\hline Pelvic-fin length & 12.3 & $15.0-15.3$ & 15.1 & 0.156 & 22.2 & $14.2-18.5$ & 15.5 & 2.025 \\
\hline \multicolumn{9}{|l|}{ Percents of head length (HL) } \\
\hline Orbital diameter & 11.9 & 24.4-26.1 & 25.2 & 0.876 & 8.0 & $19.5-26.9$ & 22.5 & 3.114 \\
\hline Snout length & 51.5 & $26.8-30.4$ & 28.8 & 1.616 & 13.3 & $6.3-16.8$ & 12.1 & 2.476 \\
\hline Interorbital width & 36.6 & $35.2-37.8$ & 36.9 & 1.213 & 10.2 & $24.9-36.5$ & 30.6 & 5.259 \\
\hline Maxillary length & 26.6 & $25.3-27.8$ & 26.7 & 1.040 & 16.8 & $38.6-43.4$ & 41.1 & 2.001 \\
\hline Lower jaw length & 28.7 & $38.7-43.1$ & 41.0 & 2.112 & 18.0 & $40.4-48.3$ & 44.3 & 3.253 \\
\hline \multicolumn{9}{|l|}{ Meristic } \\
\hline $\begin{array}{l}\text { Number of premaxillary } \\
\text { teeth in two series }\end{array}$ & $\begin{array}{l}3 \\
5\end{array}$ & $\begin{array}{l}2-4 \text { external } \\
5 \text { internal }\end{array}$ & 3.8 & 0.500 & $\begin{array}{l}4 \\
5\end{array}$ & $\begin{array}{l}\text { 3-4 external } \\
5 \text { internal }\end{array}$ & 3.6 & 0.496 \\
\hline $\begin{array}{l}\text { Number of maxillary } \\
\text { teeth }\end{array}$ & 2 & $1-3$ & 1.8 & 0.957 & 2 & $2-3$ & 2.3 & 0.987 \\
\hline $\begin{array}{l}\text { Number of longitudinal } \\
\text { series of scales }\end{array}$ & 38 & $39-41$ & 40 & 0.816 & 43 & $41-44$ & 42.6 & 0.898 \\
\hline $\begin{array}{l}\text { Number of vertical series } \\
\text { of scales: upper/lower }\end{array}$ & $6 / 6$ & $6-7(7) / 4-6(5)$ & & & $7 / 6$ & $7 / 6-5$ & & \\
\hline
\end{tabular}


Table 2. Morphometric and meristic data of Astyanax minor and Astyanax bifasciatus expressed as percents of SL and HL.

\begin{tabular}{|c|c|c|c|c|c|c|c|c|}
\hline \multirow[t]{2}{*}{$(\mathbf{m m})$} & \multicolumn{4}{|c|}{ Astyanax minor $(n=74)$} & \multicolumn{4}{|c|}{ Astyanax bifasciatus $(\mathrm{n}=\mathbf{8 6})$} \\
\hline & Holotype & Range & Mean & SD & Holotype & Range & Mean & SD \\
\hline Standard Length (SL) & 89.0 & $60.5-93.8$ & 79.3 & 6.641 & 86.0 & $49.8-125.0$ & 83.4 & 1.705 \\
\hline \multicolumn{9}{|l|}{ Percents of standard length } \\
\hline Body depth & 39.6 & $35.8-44.9$ & 40.5 & 2.131 & 32.1 & $35.2-42.5$ & 38.5 & 1.601 \\
\hline Head length & 21.9 & $22.0-25.4$ & 23.3 & 0.748 & 20.4 & $22.6-26.7$ & 24.2 & 0.832 \\
\hline Predorsal distance & 48.6 & $44.8-55.6$ & 51.5 & 1.823 & 44.0 & $48.4-55,3$ & 50.5 & 1.178 \\
\hline Pectoral-fin length & 19.4 & $18.6-23.8$ & 21.4 & 1.159 & 19.8 & $20.7-25.7$ & 22.9 & 0.981 \\
\hline Pelvic-fin length & 13.8 & $14.4-19.7$ & 17.0 & 1.424 & 16.6 & $15.3-19.9$ & 17.4 & 0.956 \\
\hline \multicolumn{9}{|l|}{ Percents of head length (HL) } \\
\hline Orbital diameter & 7.0 & $31.6-40.9$ & 34.7 & 1.842 & 5.8 & $33.0-41.5$ & 36.2 & 1.726 \\
\hline Snout length & 5.8 & $21.9-27.8$ & 24.7 & 1.089 & 20.8 & 21.6-28.4 & 25.3 & 1.272 \\
\hline Interorbital width & 7.2 & $31.1-40.3$ & 36.1 & 1.840 & 7.2 & $31.7-40.2$ & 35.9 & 1.786 \\
\hline Maxillary length & 6.8 & $21.3-27.9$ & 24.3 & 1.189 & 6.0 & $22.5-27.5$ & 24.8 & 1.139 \\
\hline Lower jaw length & 5.8 & $35.4-44.2$ & 39.2 & 1.812 & 7.6 & $33.1-43.4$ & 39.9 & 1.544 \\
\hline \multicolumn{9}{|l|}{ Meristic } \\
\hline $\begin{array}{l}\text { Number of premaxillary } \\
\text { teeth in two series }\end{array}$ & $\begin{array}{l}5 \\
5\end{array}$ & $\begin{array}{l}4-6 \text { external } \\
5 \text { internal }\end{array}$ & 5.3 & 0.528 & $\begin{array}{l}4 \\
5\end{array}$ & $\begin{array}{l}3-6 \text { external } \\
5 \text { internal }\end{array}$ & 4.1 & 0.0435 \\
\hline $\begin{array}{l}\text { Number of maxillary } \\
\text { teeth }\end{array}$ & 1 & $0-2$ & 0.9 & 0.366 & 1 & $1-2$ & 1 & 0.167 \\
\hline $\begin{array}{l}\text { Number of longitudinal } \\
\text { series of scales }\end{array}$ & 37 & $36-39$ & 37 & 0.676 & 37 & $36-40$ & 37.5 & 0.767 \\
\hline $\begin{array}{l}\text { Number of vertical series } \\
\text { of scales: upper/lower }\end{array}$ & $6 / 5$ & $6-7(6) / 5-6(6)$ & & & $6 / 5$ & $6-7 / 4-6(5)$ & & \\
\hline
\end{tabular}

Table 3. Morphometric and meristic data of Astyanax serratus and Astyanax dissimilis expressed as percents of SL and HL.

\begin{tabular}{|c|c|c|c|c|c|c|c|c|}
\hline \multirow[b]{2}{*}{$(\mathbf{m m})$} & \multicolumn{4}{|c|}{ Astyanax serratus $(\mathrm{n}=22)$} & \multicolumn{4}{|c|}{ Astyanax dissimilis $(\mathrm{n}=35)$} \\
\hline & Holotype & Range & Mean & SD & Holotype & Range & Mean & SD \\
\hline Standard length (SL) & 85.9 & $46.5-124.1$ & 91.3 & 2.026 & 65.0 & $30.2-93.0$ & 62.9 & 1.634 \\
\hline \multicolumn{9}{|l|}{ Percents of standard length } \\
\hline Body depth & 23.7 & $34.2-39.7$ & 36.3 & 1.797 & 27.6 & $32.0-46.9$ & 37.7 & 3.731 \\
\hline Head length & 21.0 & $20.2-28.8$ & 27.0 & 1.073 & 17.4 & $24.0-27.9$ & 26.1 & 0.872 \\
\hline Predorsal distance & 40.0 & $49.0-54.5$ & 51.2 & 1.429 & 34.0 & $49.3-54.4$ & 51.6 & 1.144 \\
\hline Pectoral-fin length & 16.9 & $16.9-21.7$ & 19.8 & 1.142 & 14.0 & $18.0-25.6$ & 22.2 & 1.594 \\
\hline Pelvic-fin length & 14.5 & $14.5-18.7$ & 16.3 & 1.110 & 10.5 & $13.4-18.9$ & 16.5 & 1.227 \\
\hline \multicolumn{9}{|l|}{ Percents of head length (HL) } \\
\hline Orbital diameter & 5.7 & $24.1-36.4$ & 28.7 & 2.749 & 6.2 & $28.7-41.9$ & 35.4 & 3.275 \\
\hline Snout length & 6.0 & $21.2-28.3$ & 25.7 & 1.606 & 5.0 & $22.0-28.2$ & 24.5 & 1.394 \\
\hline Interorbital width & 7.6 & $35.0-43.9$ & 40.2 & 2.038 & 5.5 & $33.1-39.4$ & 36.0 & 1,607 \\
\hline Maxillary length & 8.6 & $23.8-30.3$ & 27.4 & 1.526 & 6.2 & $24.3-29.2$ & 26.7 & 1.097 \\
\hline Lower jaw length & 5.9 & $43.9-48.9$ & 45.9 & 1.381 & 4.8 & $38.8-45.2$ & 41.8 & 1.572 \\
\hline \multicolumn{9}{|l|}{ Meristics } \\
\hline Number of premaxillary & 4 & 3-5 external & 4.0 & 0.309 & 4 & 3-5 external & 4.0 & 0.273 \\
\hline teeth in two series & 5 & 5 internal & & & 5 & 4-5 internal & & \\
\hline $\begin{array}{l}\text { Number of maxillary } \\
\text { teeth }\end{array}$ & 1 & $1-4$ & 2.3 & 0.716 & 1 & $1-3$ & 1.2 & 0.457 \\
\hline $\begin{array}{l}\text { Number of longitudinal } \\
\text { series of scales }\end{array}$ & 35 & $36-40$ & 38.1 & 1.136 & 36 & $36-38$ & 36.6 & 0.631 \\
\hline $\begin{array}{l}\text { Number of vertical series } \\
\text { of scales: upper/lower }\end{array}$ & $7 / 5$ & $7 / 5-6(5)$ & & & $6 / 5$ & $5-7(6) / 5-6$ & & \\
\hline
\end{tabular}


and Santos; Astyanax altiparanae Garutti and Britski, Psalidodon gymnodontus Eigenmann and Astyanacinus goyanensis Ribeiro.

\section{Systematic Account}

3.1. Provisional key for the six species of genus Astyanax herein described from Rio Iguaçu, above Iguaçu waterfalls

1. Teeth cusps in internal premaxillary series disposed in a straight line in ventral view; larger dentary teeth tricuspid; a dark brown vertically elongated humeral blotch; usually 6 gill-rakers on first epibranchial and 10-11 on hipobranchial arch (2)

1'. Teeth cusps in internal premaxillary series forming an arch, with a concave frontal surface in ventral view; larger dentary teeth with more than three cusps; humeral dark brown blotch almost circular or slightly horizontally elongated; usually 7-9 gill-rakers on first epibranchial and more than 13 on hipobranchial arch (3)

2. Margin of third infraorbital close to margin of preopercle, leaving a narrow naked area between these bones less than $1 / 5$ of the depth of third infraorbital; teeth in external premaxillary series with only 3 cusps; maxillary bone short, forming a right angle with premaxillary when mouth is closed; a horizontally elongate dark brown caudal spot present

\section{Astyanax gymnogenis Eigenmann}

2'. Margin of third infraorbital distant from margin of preopercle, leaving a wide naked area between these bones, varying from $1 / 5$ to $1 / 3$ depth of third infra-orbital; teeth in external premaxillary series usually pentacuspid; lateral cusps minute in non-symphysal teeth; maxillary bone long, forming an obtuse angle with premaxillary when mouth is closed

Astyanax longirhinus n. sp.

3. Margin of third infraorbital close to margin of preopercle, leaving a nude area between these bones narrower than $1 / 5$ of depth of third infraorbital bone; internal premaxillary series usually 5 or 6 penta or heptacuspid teeth; humeral blotch narrow, vertically elongate (4)

3'. Margin of third infraorbital bone isolated from preopercle margin by a large nude area, $1 / 5$ or $1 / 3$ of infraorbital depth; usually 4 pentacuspid teeth on internal premaxillary series; humeral blotch horizontally elongate or inconspicuous; lateral line usually 36 to 39 scales; humeral blotch oval or circular (5)

4. Cusps of non-symphysial teeth in premaxillary internal series in straight line or in slightly concave arch in ventral view; usually more than 2 maxillary teeth; external premaxillary series with 4 to 6 teeth, penta to heptacuspidate; premaxillary internal series with 5 teeth; first branchial arch usually $21(9+13)$ to $29(12+16)$ gill-rakers; a brown narrow and vertically elongate humeral blotch

Astyanax minor n. sp.

4'. Cusps of non-symphysial teeth in premaxillary internal series, forming a very concave arch in ventral view; 1 or 2 maxillary teeth; premaxillary external series 3 to 6 pentacuspid teeth; premaxillary internal series 4 or 5 pentacuspid teeth; first branchial arch with $18(7+11)$ to $23(10+13)$ gill-rakers; two humeral brown blotches vertically elongated: first with upper portion large, followed by a post-humeral blotch diffuse and inconspicuous

Astyanax bifasciatus n. sp.

5. Humeral dark brown blotch almost oval, with a narrow vertical prolongation; mandible robust; interorbital distance almost one times in SL; bony orbital diameter almost 1.5 times interorbital distance; maxillary usually with 2 teeth; anal fin usually iii, 16 or 17; lateral line 38 or 39 scales

Astyanax serratus n. sp.

5'. Humeral blotch light brown, vertically oval; mandible slender; interorbital distance almost 1.5 in SL; bony orbital diameter almost one times in interorbital distance; maxillary usually with 1 teeth; anal fin usually with iii, 18 to 20 rays; lateral line usually with 36 or 37 scales

Astyanax dissimilis n. sp.

\subsection{Astyanax gymnogenis Eigenmann, 1911}

(Figures 1 to 3)

Astyanax gymnogenis Eigenmann, 1911:179. Typelocality: Rio Iguaçu, Porto União, Paraná, Brazil;

Astyanax gymnogenis: Fowler, 1948: 51 (ref.); Godoy, 1979: 11 (ref.); Godoy, 1979: 15 Figure 4 (lapsus calami); Severi and Cordeiro, 1994: 17 (description translated from Eigenmann, 1911); Garavello et al., 1997: 71 (diagnosis and reference for Rio Iguaçu);

Astyanax scabripinnis paranae Eigenmann, 1927: 314 (in part): 39 paratypes of Astyanax scabripinnis paranae:

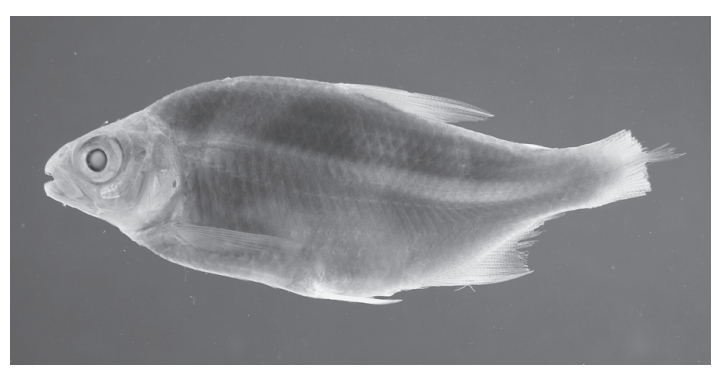

Figure 1. Lateral view of Astyanax gymnogenis, Holotype, FMNH 54707, $66.5 \mathrm{~mm}$ SL.

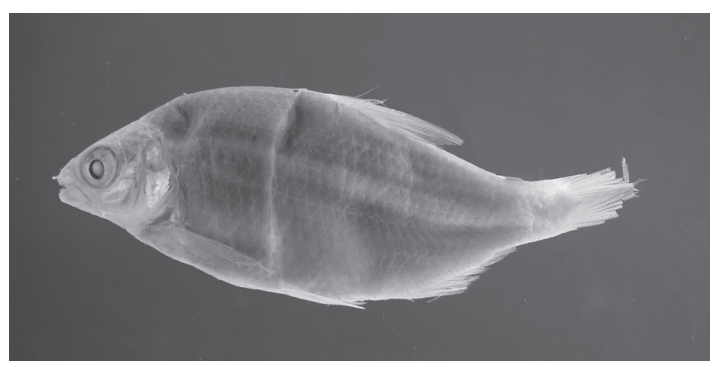

Figure 2. Lateral view of Astyanax gymnogenis, Cotype, FMNH 54708, $65.2 \mathrm{~mm}$ SL. 


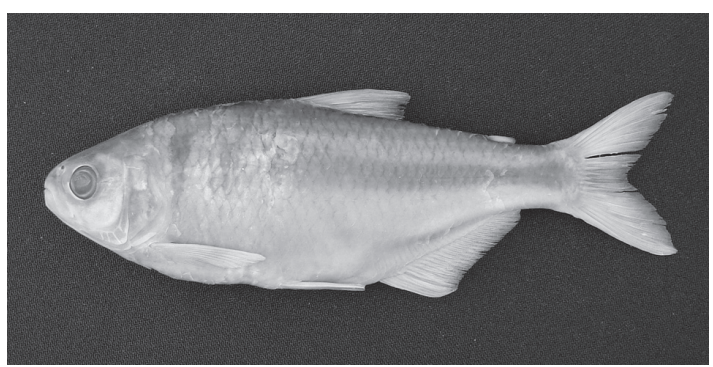

Figure 3. Lateral view of Astyanax gymnogenis Eigenmann, specimen LISDEBE 2619, $130.0 \mathrm{~mm}$ SL.

FMHN 105094, 1; FMNH 105095, 38; FMNH 105096 , 1; FMNH 105097, 195 from Serrinha, Rio Iguaçu, J. D. Haseman, 22 Dec 1908 and FMNH 57359, 25, Porto União da Vitória, Rio Iguaçu, inundated margins, swamps and lagoon; Fowler, 1948: 59 (reference, Rio Iguaçu); Godoy, 1979: 11 (reference, Rio Iguaçu).

Astyanax sp. A: Sampaio, 1988 (unpublished: 24 Figure 2); Severi and Cordeiro, 1994:19 (compilation from Sampaio, 1988): Rio Timbó and Rio Iguaçu.

Diagnosis: Astyanax gymnogenis can be separated from all other Astyanax from Rio Iguaçu by the combination of the following characters: third infraorbital narrow, leaving a broad naked area between its border and preopercle corresponding to approximately one third depth of the bone; 5 premaxillary large teeth in the inner series all in a straight line in ventral view; symphysal pair bicuspid; maxillary short in relation to premaxillary, with 1 to 3 teeth, forming a right angle with premaxillary when mouth is closed; all other premaxillary (both series) teeth and larger (anterior) dentary teeth tricuspid; first branchial arch with 6 gill-rakers in epibranchial and 10 or 11 in lower branch (ceratobranchial + hypobranchial); presence of a vertically elongated humeral dark brown blotch and a horizontally elongated dark caudal brown spot.

Description: Morphometric and meristic data are available in Table 1. Standard length ranging between 138.8 to $146.5 \mathrm{~mm}$. Body elongate and laterally compressed; greatest body depth: 35.7 to $39 \mathrm{~mm}$, situated slightly anterior to dorsal-fin origin; predorsal profile concave from region just above eye to end of occipital process, convex from this point to dorsal fin origin. Dorsal fin base in a straight line; postdorsal profile slightly convex to adipose fin; ventral profile of head almost straight, strongly convex from pectoral origin to anal fin origin; anal fin base in a straight line. Head length: 22.9 to $25.1 \mathrm{~mm}$. Snout pointed; snout length: 26.8 to $30.4 \mathrm{~mm}$. Mouth small, terminal; upper jaw protrude slightly beyond lower jaw. Lower jaw delicate, length: 38.7 to $43.1 \mathrm{~mm}$. Maxillary wide and long, maxillary length: 25.3 to $27.8 \mathrm{~mm}$, reaching a vertical line through anterior border of pupil, forming a right angle with premaxillary when mouth is closed. Eye small, bony orbital diameter: 24.4 to $26.1 \mathrm{~mm}$. Interorbital distance: 35.2 to $37.8 \mathrm{~mm}$. Third infraorbital narrow, leaving a broad naked area between its posterior margin and preopercle, depth corresponding approximately one third of this bone. Gill-rakers moderate in size; first branchial arch: 6 rakers in epibranchial and 10-11 in ceratobranchial + hypobranchial.

Premaxillary teeth in two series; external series with: 2-4 tricuspid teeth; internal with 5 teeth; teeth at symphysis bicuspid, others tricuspid. Maxillary with 1-3 teeth; teeth slightly compressed: 1 to 3 cusps. Dentary with 4 large anterior tricuspid teeth, followed ahead with a smaller tricuspid tooth and several minute teeth with 2 or 3 cusps.

Dorsal-fin ii, 8-9. Its origin nearer tip of snout than caudal-fin origin; predorsal distance: 51.7 to $54.1 \mathrm{~mm}$. Pectoral fin i, 12-13. Pectoral fin short, length: 19.6 to $20.1 \mathrm{~mm}$, not reaching pelvic-fin origin, with 3 scales between tip of pectoral fin longest ray and pelvic-fin origin. Pelvic fin i, 7-8 rays, short, 15.0 to $15.3 \mathrm{~mm}$ in length, not reaching anal-fin origin; distance between tip of pelvic fin longest ray and anal-fin origin approximately half pectoral-fin length; pelvic-fin origin just anterior to dorsal-fin. Anal-fin: iii, 18-20 rays; origin posterior to vertical through posterior end of dorsal-fin base. No hooks in anal and pelvic-fin rays.

Lateral line 39-41 perforated scales. Scales above lateral line 7; scales below lateral line 5. Longitudinal scale series around caudal peduncle: 16; an axillary scale dorsal to pelvic-fin origin, near one fourth of pelvic-fin length; scale sheath at first third of anal-fin base. Occipital process: 3 scales in each side; predorsal series: 13 scales and preventral scales not forming in regular series.

Color in alcohol: Ground color range from creamy yellow to pale brown; ventral region pale brown with few chromatophores. Chromatophore concentration gradually increases from lateral line to dorsal region. Dorsal region dark, a vertical humeral light brown blotch and a horizontal lateral stripe slightly silvery, inconspicuous and pale at origin, increasingly darker posteriorly fused to caudal spot; caudal spot present at posterior end of caudal-peduncle and base of caudal-fin rays, extending to end of mid caudal-fin rays. Dorsal portion of eye above pupil darkish; pectoral and pelvic fins whitish; dorsal fin slightly darker due to chromatophore concentration; anal fin whitish except its margin; caudal-fin marginate and with higher chromatophore concentration.

Distribution: All specimens from Rio Timbó, medium and lower Rio Iguaçu.

Comments: The specimens from populations of A. gymnogenys here studied have some small differences when compared with holotype and cotype. The caudal spot current in fresh collected specimens is absent in holotype; the predorsal region is rounded forming a keel as in cotype but not in holotype; maxillary with 1 to 3 teeth and only 1 maxillary teeth in A. gymnogenys holotype. The distance between pectoral and anal-fin origins is greater than distance between anal-fin origins to base of caudal fin. In cotype of A. gymnogenys these measurements are equidistant. Also orbital diameter in fresh specimens is narrow than in the specimens of type series. 
Eigenmann (1911) described Astyanax gymnogenys based on two specimens from Rio Iguaçu at União da Vitoria, central border of Paraná and Santa Catarina. It is possible that differences observed between type specimens and the fresh specimens studied are due to allometric growth rates, which could be considered as specific variation of A. gymnogenis. Also the poor conservation status of type material may perhaps correspond to upper described deformation.

Otherwise, the examination of paratype series of Astyanax scabripinnis paranae deposited in Field Museum (FMNH 54770) from ichthyological material collected by Haseman at Serrinha, Rio Iguaçu, Paraná, revealed that they comprise two species. From them, 39 specimens proved to be pertinent to Astyanax gymnogenis and they were separate from the lot FMNH 54770 of Astyanax scabripinnis paranae original series receiving numbers: FMNH 105094 (1 specimen) and 105095 (38 specimens). Also lots FMNH 57359 (25), FMNH 105096 (1) and 105097 (195) from Serrinha, and União da Vitória (Porto União), Paraná, revealed to be valid as Astyanax gymnogenis Eigenmann. So, those paratypes of Astyanax scabripinnis paranae are herein integrated as Astyanax gymnogenis, since specimens have tooth arcades and general features which permit the identification of this last species.

Type material examined: Brazil: Paraná: FMNH 54707, Holotype, 66.5 mm SL, Porto União, Haseman, 1908; FMNH 54708, Cotype, 65.2 mm SL, Porto União, Haseman, 1908; FMNH 57359, 25; FMHN 105094, 1: FMNH 105095, 38; FMNH 105096, 1 and 105097, 195 (paratypes of Astyanax scabripinnis paranae not measured): Serrinha, Rio Iguaçu, J. D. Haseman, 22 Dec 1908.

Non type material examined: Brazil, Paraná: Quedas do Iguaçu, Rio Iguaçu: LISDEBE 2617, 54, 71.8-144.4 mm SL, downstream of Salto Osório dam, J. C. Garavello, A. S. Soares, and J. C. Soares, 30 Nov-6 Dec 1989; LISDEBE 2618, 7, 75.3-133.1 mm SL, downstream of Salto Osório dam, J. C. Garavello, A. S. Soares and J. C. Soares, 14-17 Jan 1990. Laranjeiras do Sul: Rio Iguaçu: LISDEBE 2619, 33, 74.8-153.1 mm SL, downstream of Salto Santiago dam, between Laranjeiras do Sul and Chopinzinho, J. C. Garavello, A. S. Soares, R. J. Rodrigues, M. J. Weber and M. M. Paschoa, 5-10 Nov 1990; Candoi: LISDEBE 2620, 22, 88.0-119.7 mm SL, Candoi, Rio Cavernoso, tributary of Rio Iguaçu near Candoi, J. C. Garavello and A. S. Soares, 6 Dec 1998; LISDEBE 2621, 1, 132.3 mm SL, Rio Jordão, tributary of Rio Iguaçu, near Estância Santa Clara, J. C. Garavello, 31 Oct/5 Nov 1989. Santa Catarina: Porto União: Rio Timbó: LISDEBE 2622, 1, 146.2 mm SL, Rio Timbó tributary of Rio Iguaçu, at $500 \mathrm{~m}$ below the rapids, Colônia São Pedro, J. C. Garavello, J. M. M. Gomes and Surhema collectors, 7-9 Jun 1979; LISDEBE 2623, 3, 63.4-75.5 mm SL, Rio Timbó, approximately $500 \mathrm{~m}$ below the rapids, Colônia São Pedro, J. C. Garavello, J. M. M. Gomes and Surhema collectors, 12-14 Sept. 1979; LISDEBE 2624, 1, 120,4 mm SL, Rio Timbó, tributary of Rio Iguaçu, Colônia São Pedro, J. C. Garavello and UFSCar collectors, 18-19 Nov 1986.

\subsection{Astyanax longirhinus new species (Figure 4)}

Astyanax sp. G: Garavello et al., 1997: 73 (diagnosis and reference for Rio Iguaçu).

Holotype: MZUSP 105954, 156.9 mm SL, Rio Iguaçu downstream of Salto Santiago dam, between Laranjeiras do Sul and Chopinzinho, Laranjeiras do Sul, Paraná, Brazil. J. C. Garavello, A. S. Soares, R. J. Rodrigues, M. J. Weber and M. M. Paschoa, 5-10 Nov 1990.

Paratypes: Brazil, Paraná: MZUSP 105955, 1, $182.4 \mathrm{~mm}$ SL Rio Iguaçu reservoir of Salto Segredo dam, Nupelia collectors, no date; LISDEBE 2599, 1, $118.9 \mathrm{~mm}$ SL, same locality and collectors of holotype; FMNH 105094, 1, 103.5 mm SL, Serrinha, Rio Iguaçu, J. D. Haseman, 22 Dec 1908; FMNH 105095, 38, 6.3-103.3 mm SL, Serrinha, Rio Iguaçu, J. D. Haseman, 22 Dec 1908; NUP 10152, 16, 86.3-186 mm SL, Rio Iguaçu, reservoir of Salto Segredo hydroelectric dam, Nupelia collectors, 11 Jan 1994. Santa Catarina: MZUSP 105956, 1, 177 mm SL, Porto União, Rio Timbó, tributary of Rio Iguaçu at Colônia São Pedro, J. C. Garavello, A. S. Soares and J. C. Soares, 20-22 Nov 1986; LISDEBE 2598, 4, 120-149.3 mm SL, Porto União, Rio Timbó, tributary of Rio Iguaçu, Colônia São Pedro: J. C. Garavello, A. S. Soares and J. C. Soares, 20-21 Nov 1986; LISDEBE 2600, 3, 142-148 mm SL, Porto União, Rio Timbó, tributary of Rio Iguaçu, Colônia São Pedro, J. C. Garavello, J. M. M. Gomes and Surhema collectors, 12-14 Sept 1979.

Diagnosis: Astyanax longirhinus n. sp. can be distinguished from all other Astyanax from Rio Iguaçu by combination of following characters: third infraorbital narrow and deep, not in contact with preopercle, leaving an ample naked area between these bones. Teeth of premaxillary series straight; symphysal teeth of premaxillary internal series and dentary teeth tricuspid; teeth on premaxillary external series usually tricuspid, with lateral cusps minute when pentacuspid; remaining teeth in premaxillary internal series pentacuspid. Maxillary bone long, forming an obtuse angle with premaxillary bone when mouth is closed. Dentary large and provided with 4 large tricuspidate, followed by 3-5 tricuspid or pentacuspid teeth.

Description: Morphometric and meristic data are presented in Table 1. Standard Length ranging between 86.3-186.0 mm. Body moderately high and elongate, laterally compressed; greatest body depth sited just anterior

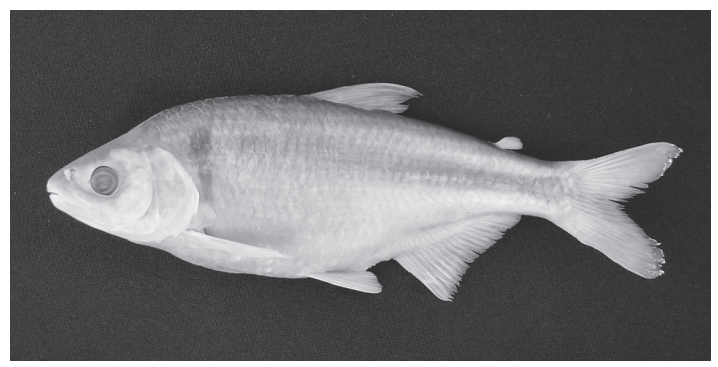

Figure 4. Lateral view of Astyanax longirhinus new species, Holotype, MZUSP 105954, 156.9 mm SL. 
to dorsal-fin origin, ranging between 34.4-59.4 mm. Dorsal profile of head almost straight and elongate; predorsal profile slightly convex from occipital process to origin of dorsal-fin; dorsal fin base straight inclined; postdorsal profile slightly convex from dorsal fin insertion to base of caudal peduncle; caudal peduncle elevated; ventral profile slightly convex from anterior lower jaw to anal opening; anal fin base almost straight.

Head length: 22.3-49.3 mm. Snout thin and elongate; snout length: 6.3-16.8 mm. Eyes in adults, as large as one half of snout length; orbital diameter: 6-10.8 mm. Interorbital distance: 6.2-18.0 mm. Mouth terminal; premaxillary horizontally aligned; maxillary long, somewhat inclined and reaching a vertical line through mid-pupil; maxillary bone forming an obtuse angle with premaxillary when mouth is closed; maxillary length range: 8.6-21.4 mm. Lower jaw narrow, dentary weak, elongate, adjusting under the premaxillary; lower jaw length: 9.0-23.6 mm. Third infraorbital not in contact with preopercle and with a naked area, large as 1/3 of infraorbital between them. First branchial arc: 7 gill-rakers in epibranchial and 9 in lower branch (ceratobranchial + hipobranchial).

Premaxillary teeth disposed in two series. External series with 3-4 large tricuspid teeth; internal series with 5 symmetric teeth; teeth in premaxillary internal series and large teeth on dentary tricuspidate; non-symphysal teeth pentacuspid and with the most lateral cusps very minute and inconspicuous. Maxillary with 2-3 small tricuspid compressed teeth with inconspicuous lateral cusps. Dentary with a single series of 4 tricuspidate symphysal teeth, an extra lateral cusps minute when pentacuspid, followed by a variable number of 3-5 cuspidate teeth decreasing in size.

Dorsal-fin ii, 9 rays: $13.5-35 \mathrm{~mm}$ in the longest ray; dorsal-fin origin more distal from the tip of snout than the base of caudal fin rays. Pectoral-fin: 17.5-32.0 mm long, not reaching the pelvic fin origin, and covering eigth scales of body when adpressed; i, 11 branched rays. Pelvic fin 1,7 rays: $16.0-27.0 \mathrm{~mm}$ long, not reaching anal fin base; situated slightly after the vertical through dorsal fin origin and covering anal opening when adpressed. Anal fin ii (iii), 18-20 rays: $9.5-22.8 \mathrm{~mm}$; anal fin origin at vertical through tip of dorsal fin. No hooks in pelvic and anal fins. Lateral line 41-44 perforated scales; scales above lateral line 7 and under, usually 6. Longitudinal series of scales around caudal peduncle: 16; axillary scale dorsal to origin of pelvic-fin. Scale sheat in base of anterior anal-fin rays. Occipital process covered with 3 scales in each side. Scales of predorsal, postdorsal, preventral and preanal regions not formed in regular series.

Color in alcohol: Ground color creamy yellow; ventral region yellowish, with chromatophore concentration increasing gradually towards dorsal region; dorsal region slight brown with a large dark brown humeral bar vertically running by almost entire body depth; a conspicuous horizontal lateral silvery stripe as large as two series of scales running above lateral line, from posterior opercular region to end of caudal fin. A dark brown fine line running from ending caudal peduncle to beyond mid caudal fin rays, following the silvery stripe. Pectoral and pelvic fins yellowish; anal fin slightly brown with chromatophores concentrated at margins and membranes of anterior rays; dorsal and caudal fin rays slightly darker than the remaining fin.

Color in life: Ground color slight brown at dorsum, a conspicuous dark brown vertical humeral blotch, and a large horizontal shine metallic silvery bar along lateral line. Abdomen yellow, sometimes orange at caudal fin, which is yellow or especially orange. Dorsal and pelvic fins yellowish; caudal and anal fins rays darker than others.

Etymology: The name longirhinus after Latin, longi = elongated and Greek, rhinos = nose. Meaning: long nose, in allusion to an elongated snout of this species, distinctive in Astyanax.

Distribution: This species is only known from medium and lower Iguaçu Basin.

Comments: With reference to Iguaçu species of Astyanax herein described, only Astyanax longirhinus and Astyanax gymnogenis has teeth on internal tooth series of premaxilla forming a straight line. It differs from remaining Iguaçu Astyanax species that have teeth of internal tooth series with small cusps forming an arch.

\subsection{Astyanax minor new species (Figure 5)}

Astyanax eigenmanniorum Eigenmann, 1921: 310 (in part): specimens FMNH 54740, 74, from the locality of Rio Iguaçu, Porto União, Santa Catarina, J. D. Haseman, 1908.

Astyanax eigenmanniorum Fowler, 1948: 44 (reference in part, Iguaçu basin).

Astyanax sp. C: Sampaio, 1988 (unpublished: 40, Figure 5); Severi and Cordeiro, 1994: 23 (compilation from Sampaio, 1988: Iguaçu basin); Garavello et al., 1997: 72 (diagnosis and reference for Rio Iguaçu); Ingenito et al., 2004:29 (identification key).

Holotype: MHNCI 3028, 89.0 mm SL, Type-locality: Rio Mato Grande, Águas Claras, Piraquara, Paraná, Brazil, J. C. Ribeiro and A. Matos Prado, Jun 1983.

Paratypes: Brazil, Paraná: MZUSP 105957, 6, 6985. 2 mm SL, São José, dos Pinhais, Rio Iguaçu, marginal ponds, J. C. Garavello and F. A. A. Sampaio, 29 Dec 1984; MZUSP 105958, 4, 15.7-42.9 mm SL, Araucária, ribeirão das Onças at Contenda - Araucária border, N. A. Menezes, S. H. Weitzman and F. A. A. Sampaio, 3 April 1985;

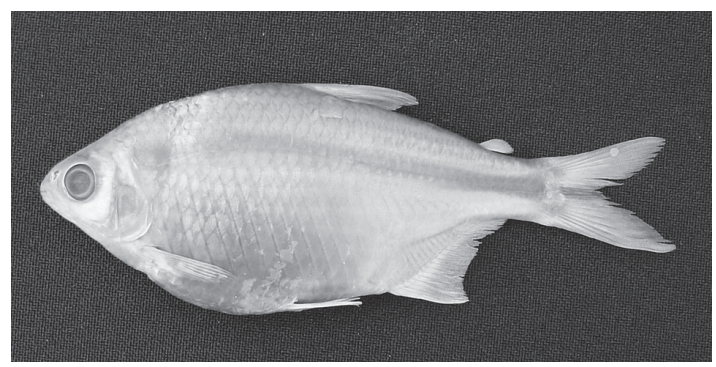

Figure 5. Lateral view of Astyanax minor new species, Holotype, MHNCI 3028, 89.0 mm SL. 
MZUSP 105959, 8, 65.0-78.7 mm SL, São José dos Pinhais, flooded marginal pools of Rio Iguaçu, J. C. Garavello and F. A. A. Sampaio, 27 Dec 1984; MHNCI 12333, 16, 63.779.3 mm SL, Curitiba, Rio Iguaçu, Parque Regional do Iguaçu, Cerdeira, Silva and J. C. Ribeiro, 28-30 April 1981; MHNCI 3381, 1, 76.5 mm SL, Piraquara, Rio Piraquara, J. C. Ribeiro and Dambros, Aug 1983; MHNCI 12334, 5, 70.9-76.8 mm SL, Piraquara, Rio Itaqui, A. M. Cordeiro and J. C. Ribeiro, 9 Octo1986; MHNCI 863, 1, $54.4 \mathrm{~mm}$ SL, Araucária, Rio Iguaçu, R. Langue and Palmeira, Jun 1960; MHNCI 3034, 1, 50.6 mm SL, Araucária, Rio das Onças, J. C. Ribeiro and A. M. Prado, May 1983; MHNCI 3078, 3085, 3088, 3089, 4, 56.1-61 mm SL, Agudos do Sul, Rio da Várzea, J. C. Ribeiro and A. M. Prado 22 April 1983; MHNCI 12335, 1, 83.5 mm SL, Agudos do Sul, Rio da Várzea, J. C. Ribeiro, A. M. Prado and Dambros, 18 Nov 1983; MHNCI 3096-3098, 3104-3108, 3111, 3113, 3116, 3120. 3122, 3123, 3129,14, 61.7-78.3 mm SL, Agudos do Sul, Rio da Várzea, Mandirituba, J. C. Ribeiro and A. M. Prado, Jun 1983; MHNCI 12336, 2, 74.4 and $89.1 \mathrm{~mm}$ SL, Palmas, Rio Iguaçu, approximately $4-5$ km downstream from the confluence with Rio Iratim, W. B. Wosiacki and Germano, 6-12 Jun 1987; MHNCI 12337 , 3, 71.2-77.4 mm SL, Pinhão, Rio Iguaçu, near confluence with Rio dos Touros, A. M. Cordeiro and W. B. Wosiacki, 4-10 May 1987; MHNCI 12338 3, 69.2-73.1 mm SL, Araucária, Rio Passauna, J. C. Ribeiro, 23 Sept 1986; MHNCI 12339 1, 61.2 mm SL, Araucária, Rio Passauna, main river, A. M. Cordeiro and J. C. Ribeiro, 30 Nov 1986; LISDEBE 2601, 3, 35.4-85.7 mm SL, Piraquara, Rio Irai, bridge at Encanamento Road, J. C. Garavello and F. A. A. Sampaio, 27 Dec 1984; LISDEBE 2602, 2, 71.9 and 80 mm SL, São José dos Pinhais, Rio Iraí, near Encanamento Road, J. C. Garavello and UFSCar collectors, 3 April 1985; LISDEBE, 2603, 2, 27.7 and $37.2 \mathrm{~mm} \mathrm{SL}$, riacho Serrinha, Engenheiro Bley, J. C. Garavello, J. M. M. Gomes and Surehma collectors, 12 Nov 1980; LISDEBE 2604, 4, 65.1-72.6 mm SL, Rio Negro, Mafra at Rio Negro border of Santa Catarina, J.C. Garavello and UFSCar collectors, 2 April 1985; LISDEBE 2605, 2, 84.3 and 90 mm SL, União da Vitória, Rio Iguaçu, Surehma, 10-13 Jun 1979; LISDEBE 2606, 171, 66-90 mm SL, São Jose dos Pinhais, Rio Iguaçu, marginal ponds at Avenida Marechal Floriano Peixoto, in front of the acess to Parque Regional do Iguaçu, J. C. Garavello and UFSCar collectors, 27-28 Dec 1984; LISDEBE 2607, 13, 42.4-83.6 mm SL, São Jose dos Pinhais, Rio Iguaçu, marginal ponds at Avenida das Torres, vicinity of Reserva de Cambuí, J. C. Garavello and UFSCar collectors, 29 Dec 1984; LISDEBE 2608, 1, 78.5 mm SL, Quedas do Iguaçu, Rio Iguaçu, downstream of Salto Osório dam, J. C. Garavello, A. S. Soares and J. C. Soares, 30 Oct/6 Nov 1989; LISDEBE 2609, 4, 79.4-96 mm SL, Quedas do Iguaçu, Rio Iguaçu, downstream of Salto Osório dam, J. C. Garavello, A. S. Soares and J. C. Soares, 14-17 Jan 1990; LISDEBE 2610, 16. 7-81.8 mm SL, Rio Iguaçu, downstream of Salto Santiago dam, Laranjeiras do Sul, J. C. Garavello, A. S. Soares, R. J. Rodrigues, M. J. Weber and M. M. Paschoa, 5-11 Nov 1990; LISDEBE
2611, 2, 32.6-34.5 mm SL, São Jose dos Pinhais, Rio Irai, tributary of Rio Iguaçu, near the Encanamento Road, J. C. Garavello and F. A. A. Sampaio, 3 April 1985; LISDEBE 2612, 8, 34.8-38.9 mm SL, Curitiba, Rio Iraí, on road Curitiba to Paranaguá, km 6, J. C. Garavello, 28 Nov 1981. Santa Catarina: FMNH 54740, 74, 28-108. 2 mm SL, Porto União, Rio Iguaçu, J. D. Haseman, 29 Dec 1912; MZUSP 105960, 6, 61.6-70.5 mm SL, Rio Canoinhas, continuation of the Mafra to Itaiópolis highway, km 219, N. A. Menezes, S. H. Weitzman and F. A. A. Sampaio, 2 April 1985; LISDEBE 2613, 1, 93.6 mm SL, Porto União, Rio Timbó, tributary of Rio Iguaçu, Colônia São Pedro, J. C. Garavello, J. M. M. Gomes and Surehma collectors, 1214 Sept 1979; LISDEBE 2614, 6, 78.2-91.4 mm SL, Porto União, Rio Timbó, Colônia São Pedro, J. C. Garavello, J. M. M. Gomes and Surehma collectors. 16-21 Nov 1980; LISDEBE 2615, 3, 64.2-70.3 mm SL, Porto União, Rio Timbó, Colônia São Pedro, J. C. Garavello, J. M. M. Gomes and Surehma collectors, undated; LISDEBE, 2616, 2, 69 and $73.7 \mathrm{~mm}$ SL, Porto União, Rio Timbó, tributary of Rio Iguaçu, Colônia São Pedro, J. C. Garavello and F. A. A. Sampaio, 18-21 Nov 1986.

Diagnosis: Astyanax minor is distinguished from Iguaçu Astyanax by combination of following characters: infraorbital 3 deep but not in contact with preopercle, leaving a narrow naked area between its border and preopercle; premaxillary external series with 4-6, usually 5 or 6 pentacuspid or heptacuspid teeth; first branchial arch 9-12, usually 10 rakers in upper branch and 13-16, usually 14 or 15 rakers in lower branch; a narrow and elongated vertical humeral bar.

Description: Morphometric and meristic data are presented in Table 2. Standard Length: between 60.5$93.8 \mathrm{~mm}$. Body moderately elongate and laterally compressed. Greatest body depth slightly anterior to dorsal-fin origin: 35.8-44.9 mm; predorsal profile concave or moderately concave at base of occipital process; convex from occipital process to dorsal-fin origin; dorsal-fin base straight inclined; postdorsal profile slightly convex in straight line. Ventral profile convex, forming a continuous line from dentary to anal-fin; anal-fin base, a straight line or little convex.

Head length: 22.0-25.4 mm. Snout small, delicate and somewhat pointed; snout length: 21.9-27.8 mm, much smaller than eye; orbital diameter: 31.6- $40.9 \mathrm{~mm}$. Mouth small and terminal; maxillary delicate: $21.3-27.9 \mathrm{~mm}$, not reaching a vertical line through mid-pupil. Lower jaw length: 35.4-44.2 mm. Third infraorbital deep but not in contact with preopercle, leaving a narrow naked area between its border and preopercle. Gill-rakers moderate in size; first branchial arch with 9-12, usually 10 rakers in epíbranchial, and 13-16, usually 14 rakers in ceratobranchial + hipobranchial.

Premaxillary teeth armed with two series. External series with 4-6, usually 5 pentacuspid or hectacuspid teeth with the combinations: $5 / 5,6 / 5$ and 6/6. Internal series with 5 teeth; teeth at symphysis asymmetric, with 5-6 cusps: proximal cusp very small, second cusp largest, followed by small cusps; other teeth symmetrical or nearly 
asymmetrical, with 7-9 cusps; cusps forming an arch with concave frontal surface in ventral view. Maxillary with 0-2, usually 1 heptacuspid tooth; most frequent combination $1 / 1$, occasionally $1 / 0$, and rarely $2 / 0,2 / 1$ or $2 / 2$. Dentary with a single series of 4 large incisors with 7-9 cusps, followed by 2 abruptly smaller pentacuspid teeth and a variable number of minute usually tricuspid teet; teeth slightly asymmetrical due to a slight inclination to distal side and sometimes with an extra cusp on distal region.

Dorsal-fin ii, 8-10 rays; closer to tip of snout than caudal-fin origin. Pectoral-fin i, 10-14 ray; pectoral-fin length: 18.6-23.8 mm, not reaching pelvic-fin origin. Pelvic fin i, 7-8 rays. Pelvic-fin small: 14.4-19.7 mm, not reaching anal-fin origin; pelvic-fin origin slightly anterior to vertical line crossing through the dorsal-fin origin. In males, first through fifth branched rays with hooks on the ventral surface of posterior branch. Anal-fin: iii, 16-23 rays; anal-fin origin posterior to vertical line through the end base of dorsal-fin. Males with posterior unbranched ray and anterior branched rays with hooks. Hooks located on both sides of posterior surface of unbranched ray. Hooks on both sides of posterior main branch and only in posterior surface of branched rays; hooks larger and more numerous on surfaces of anterior branched rays, posterior rays without hooks.

Lateral line 36-39 perforated scales. Scales above lateral line with 6-7, usually 6; scales below lateral line usually 5-6. Longitudinal scale series around caudal peduncle: $15-17$, usually 16 scales. An axillary scale located dorsally to pelvic-fin origin. Scale sheath present at anterior analfin-rays base. Occipital process with 3 sometimes, 4 scales on each side; scales at predorsal and preanal regions not formed in regular series.

Color in alcohol: Body ground color creamy yellow and ventral region light grey Chromatophore concentrations gradually increase from lateral line to dorsal region. A narrow, vertically elongated brown blotch on humeral region. An inconspicuous horizontal lateral stripe, faint at origin, increases dark to posterior end, where it fuses to a dark caudal spot. Caudal spot present at caudal peduncle and base of caudal-fin rays extending to mid caudal-fin rays to their ends; anal and caudal fin margins darker than rest of fin due to larger chromatophore concentration.

Color in life: Body silvery bright shined with the ventral region almost white; dorsal region slightly darker than the ventral region. A humeral bar vertically elongated a horizontal lateral stripe, and caudal spot much fainter than in preserved specimens. Fins hyaline; dorsal, adipose, caudal, anal, and pelvic fins slightly yellow; pectoral fins colourless.

Etymology: From Latin the name minor $=$ small, in allusion to small body size of this species, when compared with remaining species of Astyanax from Iguaçu basin.

Sexual dimorphism: Anal-fin and pelvic-fin hooks present only in small specimens, only in males to $60.5 \mathrm{~mm}$ SL. Females larger than males; snout length and body depth proportionally larger in females; orbital diameter, length of anal, pectoral and pelvic fins larger in males.
Distribution: This species is known only from upper Iguaçu basin, found mostly in localities situated upstream of confluence with Rio Jordão.

Comments: Specimens of Astyanax minor were also compared with primary types of Tetragonopterus eigenmanniorum Cope, (ANSP 21598, 21599-21601 and 21267 and 21268). These two species showed differences on number of scales on lateral line: while minor has 36-39 perforated scales in lateral line, eigenmanniorum has only 32 . With reference to the number of gill-rakers, A. minor is a form of Astyanax with 24-28 gill-rakers in first branchial arch, while A. eigenmanniorum only retains the regular count up for the genus: 15 to 20 . Also the specimens identified by Eigenmann (1921: 310, FMNH 54740, 74 specimens from "Porto União, Rio Iguassu, Haseman, 29 Dec 1908") as A. eigenmanniorum was examined, and we conclude that those 74 specimens are, in fact, $A$. minor, and they are included in type series of this species herein described. So A. minor differ from A. eigenmanniorum and the presence of eigenmanniorum in the Iguaçu basin is here put in doubt, for despite strong collecting efforts, it has never been encountered in this basin.

\subsection{Astyanax bifasciatus new species (Figure 6)}

Astyanax fasciatus (non Cuvier, 1819: 352): Godoy, 1979: 11 (misidentification).

Astyanax sp B: Sampaio, 1988 (unpublished: 29, Figure 3); Severi and Cordeiro, 1994: 21 (compilation from Sampaio, 1988), Iguaçu basin; Garavello, Pavanelli and Suzuki, 1997: 72 (diagnosis and reference for Rio Iguaçu); Ingenito et al., 2004:29 (identification key).

Holotype: MZUSP 105961, female $86.0 \mathrm{~mm}$ SL, type locality: Rio Iguaçu, marginal ponds at Avenida das Torres, at side of Reserva do Cambuí, São José dos Pinhais, Paraná, Brazil, J. C. Garavello and F. A. A. Sampaio, 27-29 Dec 1984

Paratypes: Brazil, Paraná: MZUSP 105962, 25, 66.0-90.5 mm SL; same data as Holotype; MZUSP 105963, 3, 22.0-34.0 mm SL, Rio das Onças, AraucáriaContenda border, N. A. Menezes, S. Weitzman and F. A. A. Sampaio, 3 April 1985; MZUSP 105964, 4, 21.5-27 mm SL, Agudos do Sul, Rio da Várzea, Campo do Tenente, N. A. Menezes, S. Weitzman and F. A. A. Sampaio, 3 April 1985; MHNCI 3016 and 3022, 2, 55.0-74.3 mm SL, Piraquara, Rio Mato Grande, J. C. Ribeiro and A.

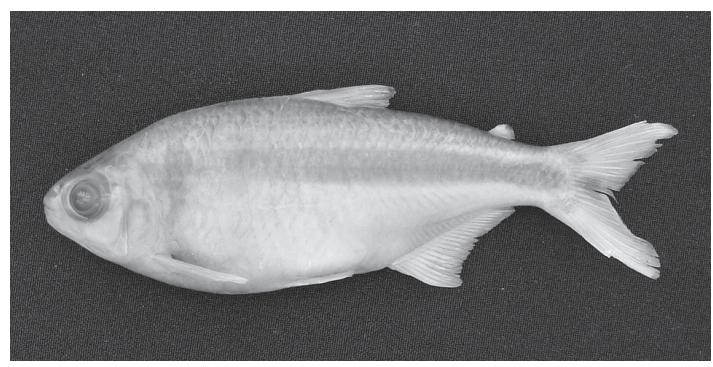

Figure 6. Lateral view of Astyanax bifasciatus new species, Paratype, LISDEBE 2645, 115.0 mm SL. 
M. Prado, April 1983; MHNCI 12340, 1, 59 mm SL, Curitiba, Rio Iguaçu, Iguaçu, Regional Park, Cerdeira, Silva and J. C. Ribeiro, 28-30 Apr 1981; MHNCI 334 1, 98.3 mm SL, Araucária, Rio Iguaçu, R. Lange, Oct 1953; MHNCI 12341, 1, 70 mm SL, Araucária, Rio Iguaçu, R. Lange and Palmeira, May 1960; MHNCI 12342, 1, 71 mm SL, Agudos do Sul, Rio da Várzea, J. C. Ribeiro, M. Prado and A. Dambros, 18 Nov 1983; MHNCI 12343, 4, 70-78 mm SL, Araucária, Rio Itaqui, A. M. Cordeiro and J. C. Ribeiro, 9 Oct 1986; MHNCI 12344, 5, 86.5-94.5 mm SL, Palmas, Rio Iguaçu, 4-5 km downstream from confluence with Rio Iratim, W. B. Wosiacki and Germano, 6-12 Jun 1987; MHNCI 12345, 7, 84.5-96.6 mm SL, Pinhão, Rio Iguaçu, near confluence with Rio dos Touros, A. M. Cordeiro and W. B. Wosiacki, 4-10 May 1987; LISDEBE 2638, 10, 45.0-95.5 mm SL, Piraquara, Rio Iraí, tributary of Rio Iguaçu, J. C. Garavello, F. A. A. Sampaio and UFSCar collectors, 27 Dec 1984; LISDEBE 2639, 1, 79.5 mm SL, São José dos Pinhais, Rio Iraí tributary of Rio Iguaçu, near Encanamento Road, J. C. Garavello, F. A. A. Sampaio and UFSCar collectors, 3 April 1985; LISDEBE 2643, 58, 75.2-121 mm SL, Quedas do Iguaçu, Rio Iguaçu, downstream of Salto Osório dam, J. C. Garavello, A. S. Soares and J. C. Soares, 30 Oct-6 Nov, 1989; LISDEBE 2644, 25, 93.6-125.0 mm SL, Laranjeiras do Sul, Rio Iguaçu, downstream of Salto Santiago dam between Laranjeiras do Sul and Chopinzinho, J. C. Garavello, A.S. Soares, J. C. Soares, R. J. Rodrigues, M. J. Weber and M. M. Paschoa, 5-10 Nov, 1990; LISDEBE 2645, 47, 72.9-129.2 mm SL, Quedas do Iguaçu, Rio Iguaçu, downstream of Salto Osório dam, J. C. Garavello, A. S. Soares and J. C. Soares, 30 Oct-6 Nov, 1989; LISDEBE, 2646, 7, 66.5-91 mm SL, same data as Holotype LISDEBE 2647, 43, 58.6-92.5 mm SL, São Jose dos Pinhais, Rio Iguaçu, marginal ponds at Marechal Floriano Peixoto avenue, in front of the acess to Parque Regional do Iguaçu, UFSCar collectors, 27 Dec 1984. Santa Catarina: MZUSP 105965, 5, 18.5-60.0 mm SL, Mafra, Rio Butiá, N. A. Menezes, S. Weitzman and F. A. A. Sampaio, 2 April 1985; MHNCI 142 and 143, 2, 105-109 mm SL, Avencal, Rio Negro, at Mafra-Rio Negro border, R. Lange, Jul 1943; LISDEBE 2640, 11, 71.2112 mm SL, Rio Negro, near bridge on Highway BR-116, Santa Catarina/Paraná State border, F. A. A. Sampaio, 2 April 1985. Porto União, Colônia São Pedro: LISDEBE 2641, 3, 72,5-107 mm SL, Rio Timbó, approximately $500 \mathrm{~m}$ below rapids, J. C. Garavello, J. M. M. Gomes and Surehma collectors, 7-9 Jun 1979; LISDEBE 2642, 3, 82.3-93.3 mm SL, Rio Timbó, tributary of Rio Iguaçu, J. C. Garavello, F. A. A. Sampaio and UFSCar collectors, 18-21 Nov 1986; LISDEBE 2648, 17, 65.5-116.6 mm SL, Rio Timbó, tributary of Rio Iguaçu, J. C. Garavello and UFSCar collectors, 20-21 Nov 1986.

Diagnosis: Astyanax bifasciatus can be distinguished from all other Astyanax from the Iguaçu basin by the combination of the following characters: infraorbital 3 deep, but not in contact with preopercle, leaving a narrow naked area between border and preopercle; premaxillary external series with 4 (rarely 5) pentacuspid teeth; non-symphysial teeth in premaxillary internal series heptacuspid; vertical humeral bar with dorsal portion much wider than ventral portion; a faint and diffuse "post-humeral" spot; lateral line with 36-40 scales, usually 37 or 38; first branchial arch with 7-9, usually 8, rakers in upper branch and 10-13, usually 12 , rakers in lower branch.

Description: Morphometrics and meristics data are presented in Table 2. Standard Length: 49.8-125 mm. Body moderately elongate, compressed laterally. Greatest body depth: 35.2-42.5 mm, slightly anterior to dorsal-fin origin. Predorsal profile convex from occipital process to dorsal-fin origin; base of dorsal-fin almost straight and postdorsal profile almost convex; ventral profile of head forming a continuous curve from lower jaw to pelvic-fin origin; usually straight from ventral fin to anal-fin origin; anal-fin base straight.

Head length: 22.6-26.7 mm. Snout short, snout length: 21.6-28.4 mm, much smaller than eye; orbital diameter 33.0-41.5 mm. Mouth terminal; maxillary long and narrow: 22.5-27.5 mm, reaching a vertical line through mid-pupil. Lower jaw delicate: $33.1-43.4 \mathrm{~mm}$. Third infraorbital large but not in contact with preopercle, leaving a narrow naked area between its border and preopercle. Gill-rakers moderate in size; epibranchial of the first branchial arch: 7-9, usually 8 rakers and $10-13$, usually 12 in ceratobranchial + hipobranchial.

Premaxillary teeth in two series; external series with 3-6 pentacuspid teeth, usually 4; observed combinations: $4 / 4,5 / 4$ or $6 / 4$, rare $4 / 3$ or $3 / 3$. Internal series usually with 5 pentacuspid teeth, rarely 4 ; teeth at symphysis asymmetric: proximal cusp small, second cusp largest, following cusps gradually smaller; other teeth symmetrical, in ventral view cusps form an arch with concave frontal surface. Maxillary with $0-2$, usually 1 pentacuspid and compressed tooth; observed combinations: $1 / 1,1 / 0$ or $2 / 1$. Dentary with a single series of 4 or 5 large pentacuspid incisors followed by 1 or 2 abruptly smaller pentacuspid teeth and a variable number of minute teeth with 1 or 2 cusps. Larger teeth symmetrical or slightly asymmetrical; tooth asymmetry due to an extra cusp on distal side or slight inclination to distal side or both

Dorsal-fin with ii, 9-10 branched rays; dorsal-fin origin usually closer to tip of snout than to caudal-fin origin; pectoral-fin i,11-14 rays; pectoral-fin length: 20.7-25.7 mm, in smaller specimens pectoral fin reaches or approaches pelvic-fin origin; in larger specimens its tip ends 1 or 2 scales in front of pelvic-fin origin. Pelvic fin short: I, 7-8 rays: $15.3-19.9 \mathrm{~mm}$, reaching anus but not anal-fin origin; its origin slightly anterior to dorsal-fin origin. In males, first through fifth branched rays with slightly antrorse hooks on the ventral surface of posterior branch. Anal-fin: iii,19-24 rays; anal-fin origin posterior to vertical line drawn ventrally from end of dorsal-fin base. In males, posterior unbranched ray and anterior branched rays with hooks. Hooks on unbranched ray on both sides of posterior surface; hooks on branched rays on both sides of posterior main branch and posterior branch only; anterior branched rays with larger and more numerous hooks; posterior rays 
without hook. Anal-fin hooks slightly recurved; smaller and weaker than pelvic-fin hooks.

Lateral line 36-40 perforated scales, usually 37 or 38. Scales above lateral line 6-7; scales below lateral line usually 5 , rarely 4 or 6 ; longitudinal series of scales around caudal peduncle 15 or 16 . Axillary scale long, reaching from dorsal to pelvic-fin origin. Scale sheath present at anterior anal-fin-rays base. Occipital process with 3 scales on each side; scales in predorsal, preventral, and preanal regions not in regular series.

Color in alcohol: Ground color of body varying from creamy to whitish; ventral region pale brown with less chromatophore concentration, that gradually increases from lateral line to dorsal region; dorsal region dark with a vertical humeral bar present; its dorsal portion much wider than ventral portion; a faint and diffuse "post-humeral" spot, posterior to humeral bar, at origin of the horizontal lateral stripe. Horizontal stripe inconspicuous at origin, and increasingly darker to posterior end; it fuses to a dark caudal spot; pelvic and anal fins reddish. Caudal spot at caudal peduncle and base of caudal-fin rays, extending to mid caudal-fin rays to their ends.

Color in life: Body silvery, sometimes slightly golden; ventral region pale, almost white; dorsal portion of eye, above pupil, red; the humeral bar, the post-humeral spot and the horizontal lateral stripe, more conspicouos than in preserved specimens. Fins hyaline: dorsal and pectoral fins slightly yellow; caudal fin with a slight orange color; anal-fin and caudal-fin margins slightly darker than remaining fin due to higher chromatophore concentration. Aquarium specimens, when disturbed, fins may acquire stronger color: caudal may reach a reddish color, pelvic fin orange and anal vary from orange, at anterior half to yellow at posterior section.

Etymology: The name bifasciatus from Latin bis = double and fascia = stripe; transverse bars crossing other bars, in allusion to two vertical dark brown bars crossing humeral region.

Sexual dimorphism: Anal and pelvic fin hooks present only in males; smaller specimens (near $49.8 \mathrm{~mm} \mathrm{SL}$ ) also bearing hooks. Females grow larger than males; lower jaw proportionally larger in females; orbital diameter and pelvic-fin length proportionally larger in males.

Distribution: This species is known only from the Iguaçu basin with large distribution.

\subsection{Astyanax serratus new species (Figure 7)}

Astyanax sp. D: Sampaio, 1988 (unpublished: 50; Figure 7); Severi and Cordeiro, 1994: 25; figure (compilation from Sampaio, 1988), Rio Iguaçu; Garavello, Pavanelli and Suzuki, 1997: 72 (diagnosis and reference for Rio Iguaçu); Ingenito et al., 2004:29 (identification key).

Holotype: MHNCI 12346, male $86.0 \mathrm{~mm} \mathrm{SL}$, Rio da Várzea, Agudos do Sul, Paraná, Brazil, J. C. Ribeiro, A. M. Prado and A. Dambros, 18 Nov 1983.

Paratypes: Brazil, Paraná: MHNCI 12347, 7, 52.0$70.2 \mathrm{~mm}$ SL, same data as holotype; MHNCI 12348, 3, 37.5-70.2 mm SL, Curitiba, Rio Barigui (lago Barigui),

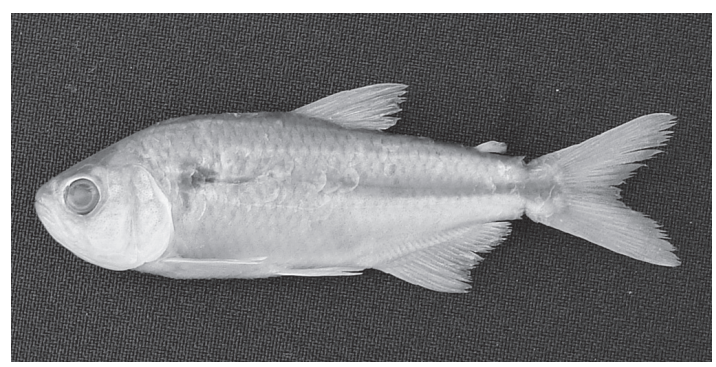

Figure 7. Lateral view of Astyanax serratus new species, Holotype, MHNCI 12346, 86.0 mm SL.

A. M. Cordeiro and J. C. Ribeiro, 8 Aug 1986; MHNCI 3033, 1, 60.5 mm SL, Araucária, Rio das Onças; J. C. Ribeiro and A. M. Prado, May 1983; MZUSP 105966, 1, 38.8 mm SL, Lapa, Rio dos Patos, N. A. Menezes, S. Weitzman and F. A. A. Sampaio, 3 April 1985; LISDEBE 2625, 2, 110.3 and 111.2 mm SL, São Mateus, Rio Iguaçu, near the confluence with Rio Potinga, J. C. Garavello, J. M. M. Gomes and Surehma collectors, 8-9 April 1980; LISDEBE 2626, 5, 78.3-107.5 mm SL, Quedas do Iguaçu, Rio Iguaçu, downstream Salto Osório dam, J. C. Garavello, J. M. M. Gomes and Surehma collectors, 13-15 Nov 1980; Santa Catarina: MHNCI 173, 1, 120 mm SL, Rio Negro, Avencal, N. Firigote, Oct 1943; Porto União, Colônia São Pedro: MZUSP 105967, 3, 82.0-100.4 mm SL, Rio Timbó, approximately 500 metres below rapids, J. C. Garavello, J. M. M. Gomes and Surehma collectors, 7-9 Jun 1979; MZUSP 105968, 6, 79.5-108 mm SL, Rio Timbó, approximately 500 metres below rapids, J. C. Garavello, J. M. M. Gomes and Surehma collectors, 12-14 Sept 1979; LISDEBE 2627, 1, 86.5 mm SL, Rio Timbó, approximately 500 metres below rapids, J. C. Garavello, J. M. M. Gomes and Surehma collectors, 16-21 Nov 1979; LISDEBE 2628, 1, 95.5 mm SL, Rio Timbó, tributary of Rio Iguaçu, J. C. Garavello and UFSCar collectors, 20-21 Nov 1986.

Diagnosis: Astyanax serratus n. sp. can be distinguished from all other Astyanax from Iguaçu basin by combination of the following characters: infraorbital 3 narrow and deep but not in contact with preopercle, leaving a naked area approximately $1 / 5$ of height between border and preopercle; premaxillary external series with 2-5, usually 4 tricuspid teeth; non-symphysial teeth in premaxillary internal series pentacuspid; maxillary with $0-4$, usually 2 teeth; humeral spot rounded and dark, frequently with a weak and narrow vertical downward prolongation.

Description: Morphometric and meristic data are presented in Table 3. Standard length ranging between: 6.5$124.1 \mathrm{~mm}$. Body elongate, compressed laterally. Greatest body depth: 34.2-39.7 mm, situated slightly anterior to dorsal-fin origin; predorsal profile of head slightly concave to occipital process; convex from occipital process to dorsalfin origin; base of dorsal-fin almost straight. Postdorsal profile a straight line or slightly convex to caudal peduncle; ventral profile forming a continuous curve from lower jaw to anal-fin origin; anal-fin base almost straight. 
Head length: 25.2-28.8 mm. Snout small and short, snout length: 21.2-28.3 mm. Eye small, slightly larger than snout; bony orbital diameter: 24.1-36.4 mm. Mouth small and terminal; maxillary long and narrow, its length: $23.8-30.3 \mathrm{~mm}$, reaching a vertical line through eye pupil. Lower jaw relatively large and robust, its length: $43.9-48.9 \mathrm{~mm}$. Third infraorbital bone narrow and deep but not in contact with preopercle, leaving a naked area between its border and preopercle; width of naked area variable, usually corresponding to $1 / 5$ of height of infraorbital bone. Gillrakers moderate in size; first branchial arch with: 8-9, usually 8 rakers, in epibranchial and 11-13, usually 12 in ceratobranchial + hipobranchial.

Premaxillary teeth in two series, external series with 2-5 tricuspid teeth, usually 4 ; observed combinations: $4 / 4$, few $4 / 3$, rare $3 / 3,4 / 2$ or $5 / 4$ teeth formulae. Internal series with 5 teeth; teeth at symphysis tetracuspid and asymmetric: proximal cusp small, second cusp largest, and following cusps gradually smaller; other teeth pentacuspid and symmetrical; in ventral view cusps forming an arch with concave frontal surface. Maxillary: 0-4, usually 2 tricuspid teeth; most frequent combination observed: $2 / 2$, few $3 / 3$ or $2 / 1$; dentary with a single series of 4 large pentacuspid incisors sometimes with a small extra cuspid, followed by a variable number of abruptly smaller tricuspid teeth. Larger teeth gradually decreasing in size, but the insertion of second tooth is lower than insertion of third tooth, thus its largest cusp does not reach a line through the largest cusps of symphysal tooth and third tooth.

Dorsal-fin ii, 8-9, usually 9 rays. Dorsal-fin origin normally closer to tip of snout than to caudal-fin origin; pectoral-fin i,11-13, usually 12 rays; pectoral-fin not reaching pelvic-fin origin; pectoral fin length: 16.9-21.7 mm. Pelvicfin with i,6-8, usually 7 rays; pelvic fin small, its length: 14.5-18.7; in smaller specimens pelvic fins reaches analfin origin, in larger specimens it reaches the anal pore but not beyond that point; pelvic-fin origin slightly anterior to dorsal-fin origin. In males, branched rays of pelvic-fin with small, slightly antrorse hooks on ventral surface of ray; only one hook per ray-segment. Anal-fin iii,16-20, usually 16-17 branched rays; anal-fin origin posterior to vertical line through end of dorsal-fin base. In males, posterior unbranched ray and anterior branched rays with small and slightly recurved hooks; hooks on unbranched ray placed on both sides of posterior surface; hooks on both sides of main branch and on posterior branch; hooks larger and more numerous on anterior rays, posterior rays without hooks. Anal-fin hooks smaller and weaker than pelvic-fin hooks; only one hooks for each ray segment.

Lateral line 36-40 perforated scales. Scales above lateral line 6-7; scales below lateral line 5-6; longitudinal series of scales around caudal peduncle 16-20; an axillary scale dorsal to pelvic-fin origin; scale sheath at anterior anal-fin-rays base; origin of caudal fin scaled. Predorsal region usually with a regular series of 11-14 scales; scales in preventral region not forming regular series.

Color in alcohol: Ground color creamy yellow; ventral region pale, with few chromatophores; chromatophore concentration gradually increases from lateral line to dorsal region. A dark and circular humeral spot sometimes a weak and narrow vertical prolongation; a horizontal lateral stripe inconspicuous and faint at origin and increasingly darker to posterior end, where it fuses to dark caudal spot; lateral stripe with a silvery shine in some specimens Caudal spot extending to tips of mid caudal-fin rays. Pectoral and pelvic fins hyaline and with few chromatophores; dorsal, anal and caudal fins greyish, dark along the fin-membrane, between fin-rays; anterior and marginal regions of anal fin darker than remaining fin.

Color in life: Body silvery; humeral spot faint, sometimes inconspicuous; fins hyaline, sometimes with a slight yellowish tone.

Etymology: The name serratus from Latin: serra, serratilis $=$ serrae is given in allusion to numerous fin hooks on pelvic-fin of males, resembling the profile of a serrae.

Sexual dimorphism: Anal and pelvic-fin hooks present only in males; only one male without pelvicfin hooks; smaller specimens (near $46.4 \mathrm{~mm} \mathrm{SL}$ ) with hooks; females usually larger in SL than males; lower jaw slight larger in females; maxillary bone, orbital diameter, pectoral-fin, pelvic-fin and anal-fin length proportionally larger in males.

Distribution: This species is known only from Rio Iguaçu where it is widely distributed.

\subsection{Astyanax dissimilis new species (Figure 8)}

Astyanax sp. E: Sampaio, 1988 (unpublished: 60 Figure 9); Severi and Cordeiro, 1994: 27 (compilation from Sampaio, 1988), Rio Iguaçu and tributaries; Garavello, Pavanelli and Suzuki, 1997: 73 (diagnosis and reference for Rio Iguaçu); Ingenito et al., 2004:29 (identification key).

Holotype: MZUSP 105969, male $62.8 \mathrm{~mm}$ SL, Type locality: Rio Canoinhas, tributary of Rio Iguaçu near the bridge on highway BR 280 from Mafra to Itaiópolis, Canoinhas, Santa Catarina, Brazil; N. A. Menezes, S. Weitzman and F. A. A. Sampaio, 2 April 1985.

Paratypes: Brazil, Santa Catarina: MZUSP 105970, 32, 28.6-74.7 mm SL, same data as holotype; MHNCI 151, 1, 88.6 mm SL, Rio Negro, Avencal, Firigote, October 1943. Porto União, Colônia São Pedro: LISDEBE 2629, 3, 77.5-79.9 mm SL, Rio Timbó, J. C. Garavello, J. M. M.

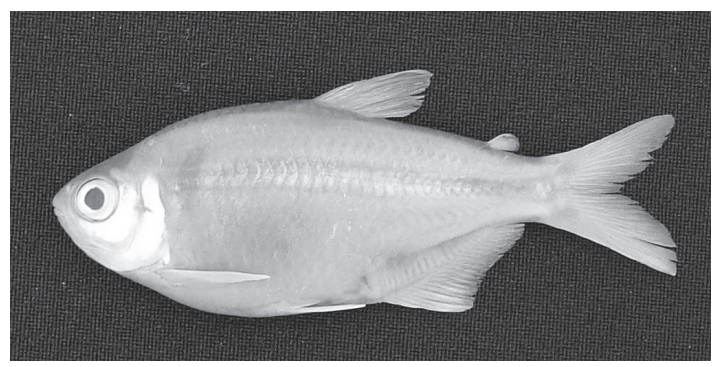

Figure 8. Lateral view of Astyanax dissimilis new species, Holotype, MZUSP 105969, 62.8 mm SL. 


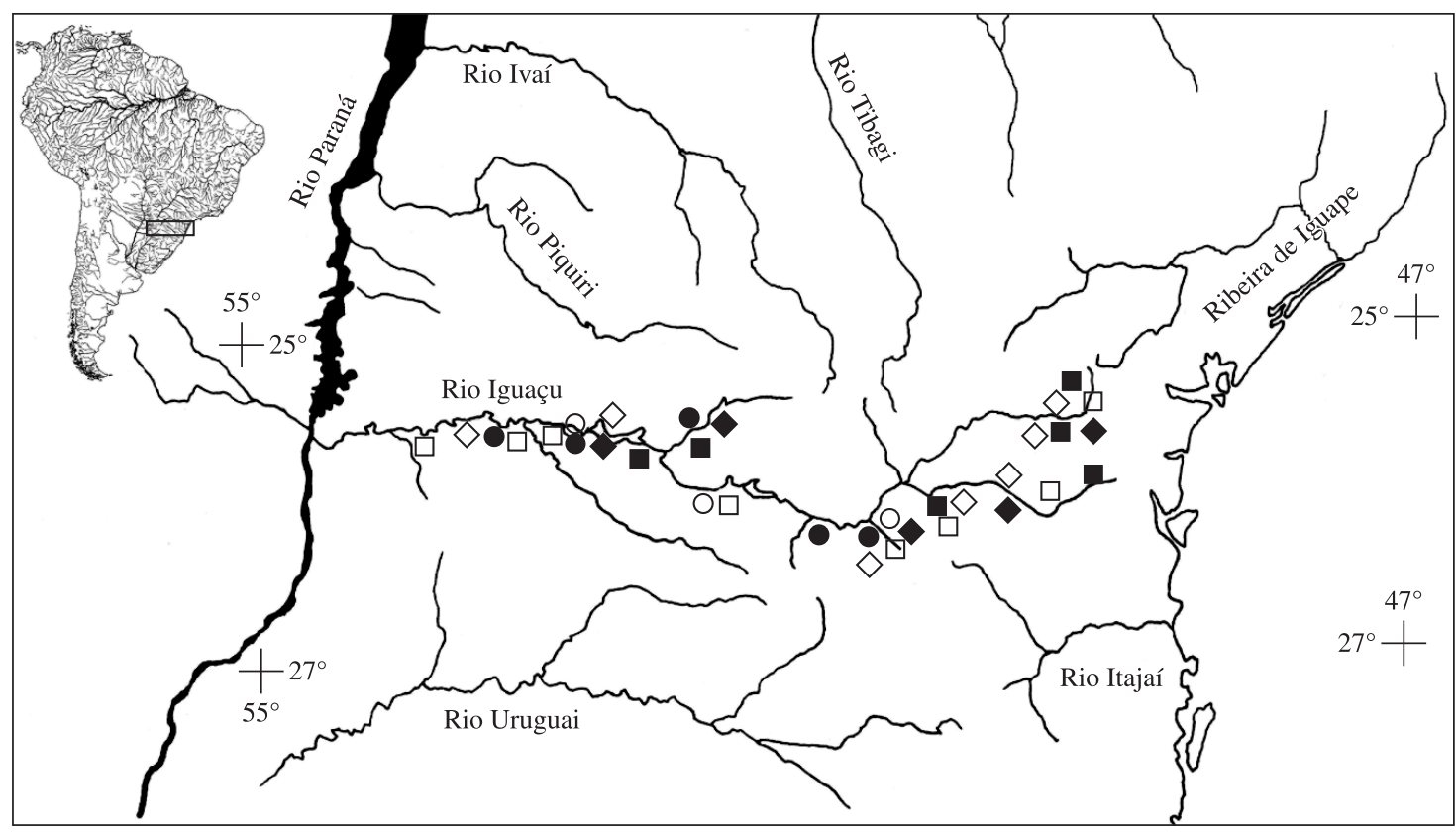

Figure 9. Map of Rio Iguaçu drainage, Paraná, Brazil, showing distribution of Astyanax gymnogenis (black circle), Astyanax longirhinus (white circle), Astyanax minor (black square), Astyanax dissimilis (white square), Astyanax serratus (black diamond) and Astyanax bifasciatus (white diamond). Symbols may represent more than one sample. Main rivers: Rio Iguaçu; Rio Chopim; Rio Negro and Rio Timbó

Gomes and Surehma collectors, 7-9 Jun 1979; LISDEBE 2630, 15, 76.3-101.1 mm SL, Rio Timbó, J. C. Garavello, J. M. M. Gomes and Surehma collectors, 16-21 Nov 1980; LISDEBE 2631, 2, 64.1-67 mm SL, Rio Timbó, J. C. Garavello, J. M. M. Gomes and Surehma collectors, undated; LISDEBE 2632, 2, 96.3-129.4 mm SL, Rio Timbó, J. C. Garavello, J. M. M. Gomes and Surehma collectors, 12-14 Nov 1979. Paraná: MHNCI 3029 and 3030, 2, 86-89.4 m SL, Piraquara: Rio Mato Grande, tributary of Rio Iguaçu, Águas Claras, J. C. Ribeiro and A. M. Prado, Jun 1983; MHNCI 3379, 1, 95.9 mm SL, Rio Piraquara, J. C. Ribeiro and A. Dambros, Aug 1983; MHNCI 12349, 3, 63.0-67. 7 mm SL, Araucária: Rio Itaqui, A. M. Cordeiro and J. C. Ribeiro, 9 Oct 1980; MHNCI 12350, 1, 74.2 mm SL, Rio Passaúna, A. M. Cordeiro and J. C. Ribeiro, 23 Sept 1986; MHNCI 12351, 1, 49.6 mm SL, Rio Guajuvira, J. C. Ribeiro and A. M. Prado, May 1983; MZUSP 105971, 3, 25.6-55.5 mm SL, Ribeirão das Onças, near road BR 476 at Araucária-Contenda border, N. A. Menezes, S. Weitzman and F. A. A. Sampaio, 3 April 1985; LISDEBE 2633, 31, 18.5-32,4 mm SL, Engenheiro Bley, riacho Serrinha, J. C. Garavello, J. M. M. Gomes and Surehma collectors, 12 Nov 1980; MZUSP 105972, 14, 26.9-53.6 mm SL, Lapa, Rio dos Patos tributary of Rio da Várzea near bridge of Road BR 427, N. A. Menezes, S. Weitzman and F. A. A. Sampaio, 3 April 1985; Agudos do Sul: MHNCI 12352, 1, 46.8 mm SL, Rio da Várzea, J. C. Ribeiro and A. M. Prado, 22 April 1983; MHNCI 12353, 11, 48.5-93.1 mm SL, Rio da Várzea, J. C. Ribeiro, A. M. Prado and A. Dambros, 18 Nov 1983; MHNCI 3099-3103, $3105,3109,3114,3115,3117,3121,3126,3128$; 3130,
3132, 3133 16, 66.2-79.2 mm SL. Mandirituba: Rio da Várzea, J. C. Ribeiro and A. M. Prado, Jun 1983; MHNCI 3094, 3119, 3120, 3125, 3127, 5, 48.2-49.1 mm SL, Rio da Várzea, Ribeiro and Prado, Jun 1983; LISDEBE 2634, 45, 23.9-69.9 mm SL, ribeirão Vermelho at bridge in BR 116, km 178, Campo do Tenente-Quitandinha border, N. A. Menezes, S. Weitzman and F. A. A. Sampaio, 2 April 1985; MZUSP 105973, 3, 63.9-69.8 mm SL, Mafra, Rio Negro, at bridge of BR-116, Paraná and Santa Catarina border, N. A. Menezes, S. Weitzman and F. A. A. Sampaio, 2 April 1985; MHNCI 12354, 1, 98.3 mm SL, Pinhão, Rio Iguaçu, near the confluence with Rio dos Touros, A. M. Cordeiro and W. B. Wosiacki, 4-10 May 1987; LISDEBE 2635, 6, 43.5-59.9 mm SL, Porto Lupion, Rio Iguaçu, J. C. Garavello, J. M. M. Gomes and Surehma collectors, 15-21 Jun 1979; LISDEBE 2636, 3, 102.9-135.8 mm SL, Quedas do Iguaçu downstream of Salto Santiago dam, J. C. Garavello, J. M. M. Gomes and Surehma collectors, 13-15 Nov 1980; LISDEBE 2637, 4, 77.3-99 mm SL, Porto Lupion, Rio Iguaçu, J. C. Garavello, J. M. M. Gomes and Surehma collectors, 15-21 Jun 1979; NUP 10151, 5, 69.8-104.1 mm SL, Rio Iguaçu, Salto Segredo, Nupelia collectors, 11 Jan 1994.

Diagnosis: Astyanax dissimilis $\mathrm{n}$. sp can be separated from all other Astyanax from the Iguaçu basin by the following combination of characters: infraorbital 3 not in contact with pre-opercle, leaving a naked area corresponding to approximately $1 / 5-1 / 4$ the height of infraorbital 3 ; premaxillary external series with 2-5, usually 4 tricuspid teeth; non-symphysal teeth in premaxillary internal series with 5 cusps forming an arch in ventral view; maxillary 
with $0-3$, usually 1 tooth; faint, narrow and elongate vertical humeral bar present.

Description: Morphometric and meristic data are presented in Table 3. Standard length ranging between 38.2-93.0 mm. Body moderately elongate compressed laterally. Greatest body depth: 32.0-46.9 mm, situated slightly anterior to dorsal fin origin. Dorsal profile varying from straight to slightly concave at head; predorsal profile convex from occipital process to dorsal-fin origin; dorsalfin insertion straight; postdorsal profile convex; ventral profile forming a continuous and somewhat pronounced curve from anterior lower jaw to anal-fin origin; anal-fin base straight.

Head length: 24.0-27.9 mm. Snout small, snout length: 22.0-28.2 mm. Eyes larger than snout; orbital diameter: 28.7-41.9 mm. Interorbital distance: 33.1-39.4 mm. Mouth terminal; maxillary long and narrow, reaching a vertical line through mid-pupil; maxillary length: 24.3-29.2 mm. Lower jaw delicate, lower-jaw length: 38.8-45.2 mm. Third infraorbital bone not in contact with preopercle; naked area between the two bones variable, usually corresponding to $1 / 5$ to $1 / 4$ of the height of infraorbital bone. Gill-rakers moderate in size; first branchial arch: 7-9, usually 8 rakers in epibranchial, and 11-12 rakers in ceratobranchial + hipobranchial.

Premaxillary teeth disposed in two series. External series: 2-5 tricuspid teeth, normally 4; most observed combinations $4 / 4$ and few $4 / 3$ dental formulae. Internal series: 4-5 teeth, usually 5; teeth at symphysis pentacuspid and asymmetric: proximal cusp small, second cusp is the largest, following cusps gradually smaller than second; other teeth in internal series pentacuspid and usually symmetrical but sometimes with one or two extra cusps; in ventral view cusps forming an arch with concave frontal surface. Maxillary: 0-3 teeth, usually one pentacuspid tooth; most observed combinations: $1 / 1$, few $2 / 2$ and $2 / 1$. Dentary with a single series of 4 large pentacuspid, sometimes hexacuspid tooth followed by a variable number of abruptly smaller 3-5 cuspid teeth. Larger teeth gradually decreasing in size but the insertion of second tooth is far below the insertion of third; its largest cusp does not reaching a line through largest cusps of symphysal and third teeth.

Dorsal-fin ii, 8-9 rays; dorsal-fin origin closer to tip of snout than to caudal fin base. Pectoral-fin: i, 11-13, normally 12 rays. Pectoral-fin not reaching pelvic-fin origin; pectoral-fin length: 18-25.6 mm. Pelvic-fin: i, 6-8, usually 7 rays; pelvic-fin length: $13.4-18.9 \mathrm{~mm}$, not reaching anal-fin origin. Pelvic-fin origin situated slightly anterior to dorsal-fin origin. In approximately $25 \%$ of the male specimens examined, branched rays with small conical or slightly antrorse hooks on the ventral surface of ray. Anal-fin: iii, 16-21, usually 18 or 19 rays; anal-fin origin posterior to vertical line through end of dorsal-fin base. In males, posterior unbranched ray and anterior branched rays with small conic or slightly recurved hooks; hooks on unbranched ray situated on both sides of posterior surface of ray; hooks on branched rays located only on both sides of posterior surface of main and posterior branches; hooks larger and more numerous in anterior branched rays; posterior rays with few minute hooks or without hooks at all.

Lateral line 36-38 perforated scales. Scales above lateral line 5-7, usually 6; scales below lateral line 5-6. Longitudinal series of scales around caudal peduncle: 13-16. An axillary scale dorsal to pelvic-fin origin; scale sheath present at anterior base of anal-fin-rays. Occipital process with 3 scales on each side; predorsal region with usually regular series of 10-12 scales; scales in preventral region not forming regular series.

Color in alcohol: Ground color creamy yellow; ventral region pale, chromatophore concentration gradually increases to dorsal region, dorsal surface of head and mid-dorsal region dark; a faint, narrow and elongated vertical humeral brown bar present. A horizontal lateral brown stripe inconspicuous at origin and increasing dark pigment to posterior end is fused to caudal spot; caudal spot situated on caudal peduncle at base of caudal-fin rays; pectoral and pelvic fins nearly whitish and with few chromatophores; dorsal, anal and caudal-fin margins darker than remaining fins, due to higher chromatophore concentration; caudal-fin grayish.

Color in life: Body silvery; a dark humeral brown spot, a horizontal lateral stripe and an inconspicuous caudal spot; fins membrane hyaline or ranging to yellowish.

Etymology: The name dissimilis from the Latin dissimile $=$ not similar, given in allusion to differences of this species in relation to the remaining species of Astyanax herein described.

Sexual dimorphism: Anal-fin and pelvic-fin hooks observed only on males; $75 \%$ of males without pelvic-fin hooks; standard length of smaller specimen with hooks: $38.2 \mathrm{~mm}$. Females usually larger than males; snout, lower jaw, interorbital distance and body depth, comparative larger in females; head length, bony orbital diameter, pectoral-fin, pelvic-fin and anal-fin length proportionally larger in males.

Distribution: This species is known only from Iguaçu basin with wide distribution.

\section{Discussion}

The five new species of genus Astyanax herein described and $A$. gymnogenis, proved to be different from the species currently identified as: A. paranahybae, A. fasciatus, $A$. schubarti, A. eigenmanniorum, A. scabripinnis paranae and $A$. altiparanae from the upper Rio Paraná basin. They are also different from Astyanax ribeirae from Xiririca, Rio Ribeira de Iguape and from A. ita, A. totae, A. varzeae and $A$. jordanensis from Rio Iguaçu. The combination of dental structure; number of scales of lateral, transversal, predorsal and preanal series; number of rays of pelvic and anal fins; number of gill-rakers and some body proportions, are responsible for exclusive diagnosis to those Iguaçu species of genus Astyanax.

Astyanax longirhinus, A. bifasciatus, A. serratus, A. minor, A. dissimilis and A. gymnogenis has the internal premaxillary 
series of five large teeth on each half premaxillary ramus, a character of historic value to recognize species of genus Astyanax. With exception of few anomalous specimens of A. dissimilis here studied that have four teeth, the remaining species always showed those five regular teeth on this series in Iguaçu Astyanax.

On the other hand, these five large teeth on this series in A. gymnogenis and A. longirhinus have three cusps straight aligned in the ventral view. A. minor, A. bifasciatus, A. serratus and $A$. dissimilis has this series with penta, hexa or heptacuspid teeth in variable arrangements. Those last species have cusps from each teeth disposed in a semicircle, forming the anterior rim of each teeth. Outside of Iguaçu, this character is shared with A. scabripinnis paranae, A. fasciatus, A. schubarti, A. altiparanae and A. eigenmanniorum from the upper Rio Paraná basin. A similar arrangement of these teeth cusps was also observed in holotype of Astyanax paranahybae. Weitzman and Vari (1986) first described this teeth arrangement in Astyanax scologaster from the Rio Negro, Amazon. On the other hand, A. ribeirae has penta or hexacuspid teeth with cusps not forming an arch as in species herein discussed.

The external large premaxillary teeth series did not shown the same constancy in teeth counts as internal series, varying in number of teeth and cusps for almost all studied species. A. gymnogenis and A. longirhinus has 3 or 4 large teeth ( 2 in few specimens) with three cusps, except for a few specimens of A. longirhinus that showed an additional and inconspicuous pair of lateral cusps on inner teeth of this series.

In addition, the dentary teeth of all species exhibit four large teeth on each side, followed by small teeth abruptly reduced in size and decreasing regularly to inner part of bone. This is another important character for diagnosing Astyanax, as described by Eigenmann (1921) and discussed by Gery et al. (1996). The symphysal pair of dentary teeth in A. gymnogenis and A. longirhinus is large and tricuspidate. A. minor, A. bifasciatus, A. dissimilis and A. serratus always showed this large pair of dentary teeth with more than three cusps. Also the species from upper Rio Paraná basin and A. ribeirae has this last configuration in their dentary teeth.

An examination of Astyanacinus goyanensis Ribeiro paratypes that has a minimum of eight teeth on each maxillary branch, permits a sure diagnosis for all Iguaçu Astyanax herein described. Also, the species from the upper Paraná basin, A. fasciatus, A. schubarti, A. paranahybae, A. eigenmanniorum and $A$. scabripinnis paranae, always showed more than one tooth on the maxillary bone. A. altiparanae as described by Garutti and Britski (2000), have maxillary teeth absent. A. gymnogenis and A. longirhinus has tricuspid maxillary teeth, similar to that from premaxillary ramus; $A$. bifasciatus and $A$. serratus has pentacuspid maxillary teeth, contrasting with the hexa and heptacuspid maxillary teeth respectively display by A. dissimilis and A. minor.

The new Iguaçu species and A. gymnogenis also showed some variation related to the size of the third infraorbital bone. As assumed by Weitzman and Vari (1986) with Astyanax scologaster, which has infraorbitals not in contact with the sensory tube of preopercle, the infraorbital bones were described as a complete series for genus Astyanax. So, A. longirhinus, A. dissimilis and A. serratus has the third infraorbital narrow and distant from preopercle, with a large nude area near $1 / 5$ to $1 / 3$ of infraorbital depth. Otherwise, A. gymnogenis has a narrow nude area less than 1/5 of infraorbital depth between these bones that is similar in A. minor and A. bifasciatus.

The gill-rakers, with the exception of A. gymnogenis and $A$. longirhinus, remained moderate in size and in low counts. It was always counted at the first left branchial arch, registering usually 6 in the epibranchial and 10 (11) in lower branch (ceratobranchial + hipobranchial), carrying a total of 16 (17) gill-rakers on each first arch. On the other hand, A. minor with 9 (10) on the epibranchial and 13 (14) on lower branch, is distinguished from the remaining species by their large counts, 22-24 gill-rakers on first branchial arch. A.bifasciatus with: 7 (8) and 10 (11-12), total of 17 to 20 gill-rakers; A serratus: 8 and 11 (12) and A. dissimilis: 7 (8) and 11 (12) also sum 17 to 20 gill-rakers. So, only A. gymnogenis and A. longirhinus have low number of gill-rakers, contrasting with A. serratus, A. bifasciatus, A. dissimilis and A. minor.

The dorsal fin with ii, 8 (9) rays remained constant for all species and it sems to be a pattern for dorsal-fin rays count for all Astyanax species from Rio Paraná basin. Pectoral-fin rays varies from i, 12 (13) rays, showing a conservative pattern for all species of Astyanax studied. Pelvic-fin with i, 7 (8) rays was verified for all species that always repeat this formulae. The anal-fin rays varied from iii, 16-20 in A. gymnogenis and A. longirhinus to iii, 16-23 in A. minor; iii, 19-24 in A. bifasciatus and iii, 16-24 in A. serratus and $A$. dissimilis.

Small hooks on rays of anal-fin are described from males of A.minor on posterior unbranched and anterior branched rays. Also, male of $A$. bifasciatus have hooks on posterior unbranched ray and on both sides of anterior branched rays of anal fin. Small and recurved hooks were also encountered on male anal-fin near to posterior margin of unbranched ray and both sides of anterior branched rays in $A$. serratus and $A$. dissimilis. On the other hand, no hooks were found on male anal-fin rays of A. gymnogenis and A. longirhinus. Those hooks on the anal-fin of these species perform the sexual dimorphism current in species of genus Astyanax as a whole.

Scales in lateral line varied from: $36-40$ in A. bifasciatus to 36-38 (39) in A. serratus, A. minor and A. dissimilis. The species A. gymnogenys have 38, (39)-40 (41) and $A$. longirhinus: 41-44 scales in lateral line. The transversal scale series varied from 6 (7) series above and 5 series under lateral line. Caudal peduncle with 16 circumpeduncular series was coincident in all species studied. Other Iguaçu species as $A$. ita include 34-36 scales on lateral line; 4.5/I/6 series of scales on transversal line, while $A$. totae have 3438 scales on lateral line and 6/I/4 series on transversal line. A. varzeae comprise $37-42$ scales on lateral line and $6 / \mathrm{I} / 5$ 
series of scales on transversal line, while A. jordanensis have 35-38 scales on lateral line and 5-6/5 scale series on transversal line. All those last species was described as very similar to A. scabripinnis. They may be easily distinguished from the Iguaçu species here described by the combination of scale counts and tooth structure. The teeth structure in $A$. ita is characterised by the presence of penta to heptacuspidate teeth on each premaxillary and dentary, while A. totae, A. varzeae and A. jordanensis exhibit tri to pentacuspid teeth on premaxillary and dentary ramus.

The color pattern of Iguaçu Astyanax includes species with ground color ranging from whitish with belly silvery or hyaline, to creamy-yellow and reddish abdominal region. This reddish ground color pattern was registered mainly in the reproductive period when fishes receive strong melanin apport, well defining their differences in coloration. With the exception of $A$. serratus, no other studied species showed a color pattern including an almost circular or oval humeral dark blotch like A. altiparanae from the upper Rio Paraná basin. While A. longirhinus and A. gymnogenis showed patterns of creamy-yellow with an elongated vertical dark brown bar on the humeral region, A. bifasciatus joined orange reddish ground color of their bodies with an evident humeral vertically elongated dark blotch and a second vertical dark brown blotch, sometimes inconspicuous. A. minor and A. dissimilis on the contrary, show a bright silvery or hyaline coloration common to the majority of Astyanax species.

This study revealed A. gymnogenis and five new species as probably endemic from the Rio Iguaçu basin. Haseman (1911b) was the first author to discuss derivation of Iguaçu ichthyofauna. He assumed that the Iguaçu waterfalls were old and the current ichthyofauna of Paraná and La Plata river basins and thus, the ichthyofauna of Rio Iguaçu, were not apt to overtake the Iguaçu falls.

The possible endemism showed by Astyanax species from Iguaçu is here considered, in relation to their congeners from the upper Rio Paraná basin. Besides evidence coming from the recognised geographical events associated with the isolation occurring since the beginning of the Iguaçu falls, the exchange of ichthyofauna, mainly in headwaters, was assumed by Weitzman et al. (1988). They check the combination of stream capture events taken from upper land areas of Rio Iguaçu, and fluctuation of sea level affecting some lower coastal regions in the past. Furthermore, they posit these facts as the main factors to explain sympatry for Mimagoniates microlepis and M. lateralis in this area.

Several arrangements of near species from the same genus, sharing different isolated basins in southeastern Brazil, could be considered in this discussion. For example, Mimagoniates microlepis and M. lateralis; Corydoras barbatus and C. paleatus as cited by Weitzman et al. (1988); Oligosarcus longirostris from Iguaçu and Oligosarcus species from southeastern Brazil as discussed by Menezes (1988); Apareiodon vittatus from Iguaçu and A. piracicabae from upper Rio Paraná as studied by Garavello (1977), and the giant species Steindachneridion melanodermatum from
Rio Iguaçu and their relatives in southeastern Brazilian basins as assumed by Garavello (2005).

In view of the recognised allopatry on Tetragonopterinae species in these southeastern basins as considered by Weitzman et al. (1988), and in view of shared ancestors in old flood valleys of the continental shell on the Brazilian coast, we may suggest that the same might have taken place near Astyanax species from Rio Iguaçu.

At the present time, the Iguaçu Astyanax show similar species in isolated coastal rivers, especially in the Rio Ribeira de Iguape. In fact, the examination of type material of Astyanax ribeirae revealed it is similar to Astyanax minor herein described. A. ribeirae and A. minor have an elevated number of tooth cusps and a high number of anal-fin rays: 24-25 (A. minor) and 26-28 (A. ribeirae - holotype). So, we may assume that ancestral forms of Iguaçu Astyanax might be retained from other isolated earlier neighbouring basins in the past.

Other important information from recent palynological studies on Cenozoic deposits of sediment from Tremembé formation, Taubaté, São Paulo needs to be considered. Those sample stratums were redated, advancing to an Oligocenic age by Lima et al. (1985). The Characiform fishes found at this Oligocenic deposit are, according to Malabarba (1998), Megacheirodon unicus, Brycon avus, Lignobrycon ligniticus and Cyphocharax mosesi. The question is: those species represent modern lineages of characins? If so, the endemism of Rio Iguaçu Astyanax, as with the modern lineages of Characiform fishes, were probably established in this basin earlier than the isolation arising from the formation of the Iguaçu waterfalls.

Consequently, it is plausible to suspect that Tetragonopterinae ichthyofauna that remain isolated at Rio Iguaçu arose from modern species derived in isolation and perhaps gave origin to the Astyanax lineage herein described. If this is correct, it is important to understand that this scenario of endemism for Astyanax species in Iguaçu is a general event, probably derived from other geographic episodes distinct from pure dispersion.

On the other hand, as indicated by Petri and Fulfaro (1983), the juvenile aspect of several geological regions of Rio Iguaçu, probably shows tectonic reactivation of several "breaks" along the basin. According to these authors, it may produce isolated amounts of water in some discontinuous regions, producing compartmentalisation. If these water supplies have existed for a long time, as Bigarella and Salamuni (1957) observe for the Curitiba basin, many environmental changes might have taken place throughout the Iguaçu basin in the past. Compartmentalisations perhaps brought about dramatic effects on ichthyofauna by introducing significant modifications on the habitat structure. In fact, fishes with reproductive migratory movements could be strongly affected, originating in the simplification of ichthyofauna, as recognised by Lowe McConnell (1975), an event that has always taken place when compartmentalisation occurs.

The evidence of compartmentalisation in Rio Iguaçu is corroborated by other recent descriptions of Astyanax 
species in this basin, as assumed by: Almiron et al. (2002), Haluch and Abilhoa (2005), Abilhoa and Duboc (2007) and Alcaraz et al. (2009). Some of these species are restricted to headwaters, Haluch and Abilhoa and Abilhoa and Duboc observe, when describing A. totae and A. varzeae. Other species are most frequent at median and low regions of this basin, such as A. ita, described by Almiron et al., which seems to be restricted to downwaters of the Iguaçu basin.

This fact may perhaps also explain the slight differences in size of orbital diameter in Astyanax gymnogenis populations herein studied in relation to type specimens and samples from other localities. Those populations may perhaps remain in isolation during recent geological times. Consequently, it will not be a surprise if other undescribed Astyanax species, derived from isolated populations, are perhaps discovered from other regions of Iguaçu. Furthermore, the major result of compartmentalisation in Iguaçu seems to be the effect on local differentiation of isolated populations, followed by continuing speciation through the basin as a whole. To finalise, a conclusion on this subject would only be possible when perhaps phylogeny of Tetragonopterinae genera in the area could be put forth.

Acknowledgements - We would like to express our gratitude to many people who made the publication of this article possible. For the loan of specimens we wish to thank: Heraldo A. Britski and José L. de Figueiredo of MZUSP; Ângelo A. Agostinho and Carla S. Pavanelli of NUP; Barry Chernoff and Mary A. Rogers of FMNH; D. Cattania of CAS and Adelinir de M. Cordeiro and Vinicius Abilhoa of MHNCI. Stanley H. Weitzman and Marylin J. Weitzman of Smithsonian Institution provided information on Astyanax gymnogenis holotype and Kevin Swagel of FMNH made photographs of Astyanax gymnogenis type series. Luis R. Malabarba of Instituto de Biociências da Universidade Federal do Rio Grande do Sul (UFRS), Scott A. Schaefer of the American Museum of Natural History (AMNH) and Monica Toledo-Piza of Instituto de Biociências da Universidade de São Paulo (IB-USP), read the manuscript giving helpful suggestions. Valdener Garutti of Universidade Estadual Paulista (UNESP) and other colleagues assisted with useful information on species of genus Astyanax. Alexandre K. de Oliveira of Departamento de Hidrobiologia at UFSCar (DHB) helped with collection management, tables and photographs, and Jose L. Birindelli of MZUSP provided the Iguaçu map. The Robert O. Bass Visitor Fund of FMNH conferred a Grant to visit the Field Museum and the Conselho Nacional de Desenvolvimento Científico e Tecnológico (CNPq), a continuing Research Grant to J.C.Garavello. CNPq also conferred a MsC. Grant to F. A. de A. Sampaio when studying at UFSCar.

\section{References}

ABILHOA, V. and DUBOC, LF., 2007. A new species of freshwater fish genus Astyanax (Ostariophysi: Characidae) from the Iguaçu basin, southeastern Brazil. Zootaxa, vol. 1587, p. 43-52.

ALCARAZ, HSV., PAVANELLI, CS. and BERTACO, VA., 2009. Astyanax jordanensis (Ostariophysi, Characidae), a new species from the rio Iguaçu basin, Paraná, Brazil. Neotropical Ichthyology, vol. 7, no. 2, p. 185-190.

ALMIRÓN, AD., AZPELICUETA, M. DE LAS M. and CASCIOTTA, JR., 2002. Astyanax ita sp. n., a new species from the Rio Iguazú basin, in Argentina (Teleostei, Characiformes, Characidae). Zoologische Abhandlungen Staatliches Museum Tierkunde Dresden, vol. 52, p. 3-10.

AZPELICUETA, M. DE LAS M., CASCIOTTA, JR. and ALMIRÓN, AE., 2002. Two new species of the genus Astyanax (Characiformes, Characidae) from the Paraná basin in Argentina. Revue Suisse Zoologie, vol. 109, no. 2, p. 243-259.

BERTACO, VA. and MALABARBA, LR., 2001. Description of two new species of Astyanax (Teleostei, Characidae) from headwater streams of Southern Brazil, with comments on the A. scabripinnis species complex. Ichthyological Explorations of Freshwaters, vol. 12, no. 3, p. 221-234.

BIGARELLA, JJ. and SALUMUNI, R., 1957. Aspectos Geográficos e Geológicos da Cidade de Curitiba e Arredores: contribuição das cadeiras de Mineralogia-Petrologia e Geologia-Paleontologia. Curitiba: Faculdade Católica de Filosofia de Curitiba.

BRITSKI, HA., 1964. Sobre uma nova espécie de Astyanax do Rio Mogi-Guassu (Pisces: Characidae). Papeis Avulsos de Zoologia, vol. 16 , no. 21 , p. $213-215$.

COPE, ED., 1894. On the fishes obtained by the Naturalist Expedition to Rio Grande do Sul. Proceedings American Philosophical Society, vol. 33, p. 84-108.

EIGENMANN, CH., 1911a. The localities where Mr. J. D. Haseman made collections. Annals Carnegie Museum, vol. 7, no. 3-4, p. 299-314.

-, 1911b. New characins in the collection of the Carnegie Museum. Annals Carnegie Museum, vol. 8, no. 1, p. 164-181.

-, 1921. The American Characidae. Memoirs Museum of Comparative Zoology, vol. 43, no. 3, p. 209-310.

-, 1927. The American Characidae. Memoirs Museum of Comparative Zoology, vol. 43, no. 4, p. 311-428.

FINK, WL. and WEITZMANN, SH., 1974. The so-called cheirodontin fishes of Central America with description of two new species (Pisces, Characidae). Smithsonian Contributions to Zoology, vol. 172, p. 1-146.

GARAVELLO, JC., PAVANELLI, CS. and SUZUKI, H., 1997. Caracterização da ictiofauna do Rio Iguaçu. In AGOSTINHO, AA. and Gomes, LC. (Eds.). Reservatório de Segredo: bases ecológicas para o manejo. Maringá: EDUEM. p. 61-84.

GARAVELLO, JC., 1977. Descrição de Apareiodon vittatus sp. n. do Rio Iguaçu e comentários sobre as espécies do gênero Apareiodon Eigenmann, 1916 (Ostariophysi, Parodontidae). Revista Brasileira de Biologia = Brazilian Journal of Biology, vol. 37 , no. 2, p. 447-455.

-. 2005. Revision of genus Steindachneridion Eigenmann and Eigenmann, 1919 (Ostariophysi, Siluriformes, Pimelodidae). Neotropical Ichthyology, vol. 3, no. 4, p. 607-623.

GARUTTI, V. and BRITSKI, HA., 2000. Descrição de uma espécie nova de Astyanax (Teleostei: Characidae) da bacia do Alto Rio Paraná e considerações sobre as demais espécies do gênero na bacia. Comunicações Museu Ciências e Tecnologia, vol. 13 , p. $65-88$.

GÉRY, J., 1977. Characoids of the World. Neptune City: T. F. H. Publications. 672 p.

GERY, J., PLANQUETTE, P. and LE BAIL, Y., 1996. Nouvelles Especes Guyanaises d'Astyanax S. L. (Teleostei, Characiformes, 
Characidae) a Epines Pelviennes, avec une Introduction Concernant le Groupe. Cybium, vol. 20, no. 1, p. 3-36.

GODOY, MP., 1979. Rio Iguaçu, Paraná, Brasil, Reconhecimento da ictiofauna, modificações ambientais e usos múltiplos dos reservatórios. Florianópolis: Eletrosul. 33 p.

GRAÇA, WJ. da and PAVANELLI, C., 2002. Astyanax altiparanae Garutti \& Britski, 2000 (Osteichthyes, Characidae) in the Iguaçu River basin. Acta Scientiarum, vol. 24, no. 2, p. 451-453.

HALUCH, CF. and ABILHOA, V., 2005. Astyanax totae, a new characid species (Teleostei: Characidae) from the upper Iguaçu basin, southeastern Brazil. Neotropical Ichthyology, vol. 3, no. 3, p. 383-388.

HASEMAN, JD., 1911a., A brief report upon the Expedition of the Carnegie Museum to Central South America. Annals Carnegie Museum, vol. 7, no. 3-4, p. 287-299.

HASEMAN, JD., 1911b., Some new species of fishes from the Rio Iguassu. Annals Carnegie Museum, vol. 7, no. 3-4, p. 374-387.

INGENITO, LFS., DUBOC, LF. and ABILHOA, V., 2004. Contribuição ao Conhecimento da Ictiofauna da bacia do Alto Rio Iguaçu, Paraná, Brasil. Arquivos Ciências Veterinárias, vol. 7 , no. 1 , p. 23-36.

LIMA, FCT., MALABARBA, LR., BUCKUP, PA., PEZZI DA SILVA, JF., VARI, RP, HAROLD, A., BENINE, R., OYAKAWA, OT., PAVANELLI, CS., MENEZES, NA., LUCENA, CA., CASATTI, MCSL., BERTACCO, VA., MOREIRA, C. and LUCINDA, PHF., 2003. Genera incertae sedis in Characidae. In REIS, R.E., KULLANDER, SO. and FERRARIS, CJ. (Eds.). Check List of the Freshwater Fishes of South and Central America. Porto Alegre: Edipucrs. 729 p.

LIMA, MR., SALARD-CHEBOLDAEFF, M. and SUGUIO, K., 1985. Étude palynologique de la formation Tremembé, Tertiary du Bassin de Taubaté, (Etat de São Paulo, Brésil) D'apres les Echantillons du Sondage no. 42 du CNP. In Coletânea de Trabalhos Paleontológicos. MME-DNPM, Rio de Janeiro, p. 379-393.

LOWE McCONNELL, RH., 1975. Fish Communities in Tropical Freshwaters. London: Longman. 546 p.
MALABARBA, MC S L. 1998. Phylogeny of Fossil Characiformes and Paleobiogeography of the Tremembé Formation, São Paulo, Brazil, In: MALABARBA, L. R., REIS, R. E, VARI, R. P., LUCENA, Z. E and LUCENA, C. A. (Eds.). Phylogeny and classification of Neotropical fishes EDIPUCRS, Porto Alegre, Brazil.

MENEZES, NA. and GERY, J., 1983. Seven new acestrorhynchin characid fishes (Osteichthyes, Ostariophysi, Characiformes) with comments on the systematics of the group. Revue Suisse Zoologie, vol. 90 , no. 3, p. 563-592.

MENEZES, NA., 1988. Implications of the distribution patterns of the species of Oligosarcus (Teleostei, Characidae) from central and southern South America. In VANZOLINI, PE and HEYER, WR. (Eds.). Proceedings of a workshop on Neotropical distributions patterns. Rio de Janeiro: Brazilian Academy of Sciences. p. 295-304.

PETRI, S. and FULFARO, VJ., 1983. Geologia do Brasil. São Paulo: USP. 631 p.

SAMPAIO, FA. de A., 1988. Estudos Taxonômicos Preliminares dos Characiformes (Teleostei, Ostariophysi) da Bacia do Rio Iguaçu, com comentários sobre o endemismo dessa fauna. São Carlos: Universidade Federal de São Carlos. 175 p. [Dissertação de mestrado].

SEVERI, W. and CORDEIRO, A. de M., 1994. Catálogo de peixes da Bacia do Rio Iguaçu. Curitiba: IAP/GTZ. 128 p.

TRAVASSOS, H. and SANTOS, RS., 1955. Caracídeos fósseis da bacia do Paraíba. Anais da Academia Brasileira de Ciência, vol. 27, no. 3, p. 297-332.

WEITZMAN, MJ. and VARI, RP., 1986. Astyanax scologaster, a new characid (Pisces: Ostariophysi) from the Rio Negro, South America. Proceedings Biological Society, vol. 99, no. 4, p. 709-716.

WEITZMAN, SH., MENEZES, NA. and WEITZMAN, M. J., 1988. Phylogenetic Biogeography of the Glandulocaudini (Teleostei: Characiformes, Characidae) with comments on the distributions of other freshwater fishes in estern and southeastern Brazil. In VANZOLINI, PE and HEYER, WR (Eds.) Proceedings of a workshop in Neotropical distribution patterns. Rio de Janeiro: Brazilian Academy of Sciences. p. 379-428. 